
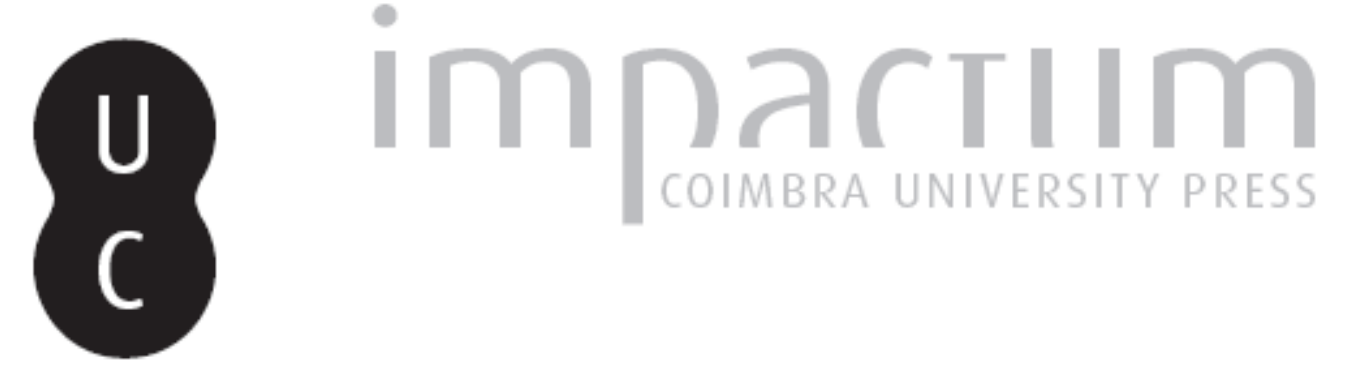

\title{
Escoamento torrencial e processos geomorfológicos na bacia da Povoação (S. Miguel, Açores): as cheias de 14 de Dezembro de 1996
}
Autor(es):
Bateira, Carlos; Resendes, João; Rebelo, Fernando
Publicado por: Associação Portuguesa de Riscos, Prevenção e Segurança
URL
persistente:
URI:http://hdl.handle.net/10316.2/40131
DOI:
DOI:https://doi.org/10.14195/1647-7723_5_1
Accessed : $\quad$ 26-Apr-2023 11:20:24

A navegação consulta e descarregamento dos títulos inseridos nas Bibliotecas Digitais UC Digitalis, UC Pombalina e UC Impactum, pressupõem a aceitação plena e sem reservas dos Termos e Condições de Uso destas Bibliotecas Digitais, disponíveis em https://digitalis.uc.pt/pt-pt/termos.

Conforme exposto nos referidos Termos e Condições de Uso, o descarregamento de títulos de acesso restrito requer uma licença válida de autorização devendo o utilizador aceder ao(s) documento(s) a partir de um endereço de IP da instituição detentora da supramencionada licença.

Ao utilizador é apenas permitido o descarregamento para uso pessoal, pelo que o emprego do(s) título(s) descarregado(s) para outro fim, designadamente comercial, carece de autorização do respetivo autor ou editor da obra.

Na medida em que todas as obras da UC Digitalis se encontram protegidas pelo Código do Direito de Autor e Direitos Conexos e demais legislação aplicável, toda a cópia, parcial ou total, deste documento, nos casos em que é legalmente admitida, deverá conter ou fazer-se acompanhar por este aviso.

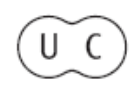




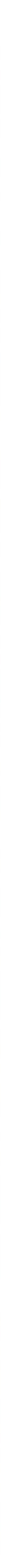




\title{
Escoamento torrencial e processos geomorfológicos na Bacia da Povoação (S. Miguel, Açores). As cheias de 14 de Dezembro de 1996
}

\author{
Carlos Bateira* \\ João Resendes** \\ Fernando Rebelo***
}

\section{Resumo:}

Depois de uma introducão sobre as cheias no conjunto da bacia da Povoação (S. Miguel, Açores), analisam-se os factores físicos e humanos que as condicionam e os processos erosivos que lhes estão associados, particularmente os que se verificam nos canais de escoamento. O estudo das cheias de 14 de Dezembro de 1996 levou ainda a algumas reflexões sobre os problemas da previsão e da prevenção das cheias rápidas.

Palavras chave:

Povoação, S. Miguel, Açores, cheias rápidas.

\section{Résumé:}

Après une introduction sur les crues dans l'ensemble du bassin de Povoação (S. Miguel, Archipel des Azores), on analyse les facteurs physiques et humains des crues et les processus erosifs associés, notamment ceux qui se sont produis à l'intérieur des chenaux d'écoulement. L'étude des crues du 14 décembre 1996 a fait réflechir sur les problèmes de la prévision et de la prévention des crues rapides.

Mots clés:

Povoação, S. Miguel, Azores, crues rapides.

\section{Abstract:}

After an introduction about floods in the whole of Povoação basin (S. Miguel, Azores Islands), the Authors analyse physical and human factors of these floods and geomorphical processes associated, namely the ones occurred in the channels. The study of the floods of the $14^{\text {li }}$ december 1996 has taken the Authors into a reflexion about prediction and prevention of flash floods.

Key words:

Povoação, S. Miguel, Azores, flash floods.

\section{Considerações gerais sobre as cheias na bacia da Povoação}

\subsection{Quadro histórico}

Há já vários séculos que a vila da Povoação é afectada por cheias. Uma simples consulta dos periódicos insulares permite compilar alguns acontecimentos que afectaram várias localidades da ilha de S. Miguel. Pelo menos desde meados do século XVIII, existem notícias sobre cheias nos concelhos da parte oriental da ilha de S. Miguel, tais como as de

\footnotetext{
* Instituto de Geografia. Faculdade de Letras. Universidade do Porto.

*** Licenciado em Geografia.

**** Instituto de Estudos Geográficos. Faculdade de Letras. Universidade de Coimbra.
}

- 5 de Outubro de 1744, Ribeira do Além, 66 mortos, 52 habitações destruídas,

- 2 de Novembro de 1896, 13 mortos na Povoação e 5 mortos na Ribeira Quente, 44 habitações destruídas,

- 14 de Novembro de 1896, 2 habitações destruídas no Faial da Terra,

- 18 de Março de 1969, Povoação (Poiso dos Pombos), Largo do Município com dois metros de sedimentos,

- 2 de Setembro de 1986, Povoação, Faial da Terra, Nordeste, Mosteiro, Bretanha, Sete Cidades e Rib $^{\text {a }}$ Quente, 3 mortos,

- 14 de Dezembro de 1996, Povoação, Ribeira Quente, Faial da Terra, etc.

- 10 de Setembro de 1997, Ribeira Quente, 1 morto,

- 31 de Outubro de 1997, cheias em toda a ilha de S.Miguel, com o balanço trágico de 29 mortos na 
Ribeira Quente ${ }^{(1)}$, provocados por um movimento em massa.

A característica mais marcante de todos os relatos diz respeito ao carácter violento das cheias, por vezes com perda de vidas humanas e destruições várias. Em quase todas as descrições se salientam dramas relacionados com os bens e as vidas que não foi possível salvar dado o carácter repentino e surpreendente das cheias. Igualmente todos os relatos dão muita importância à quantidade e à intensidade da precipitação que, para a população local é considerada frequentemente como pouco vulgar. Apesar de a amostragem se referir a um período de tempo curto (cerca de 250 anos) facilmente nos apercebemos de que o processo de escoamento que origina as cheias não pode ser exclusivamente imputado às características das bacias hidrográficas.

De igual modo, as descrições sobre a quantidade elevada de sedimentos que se depositam na área da Povoação demonstram que a colmatação do cone de dejecção aí existente é feita à custa deste tipo de processos de transporte, isto é, resultam de cheias rápidas.

Por outro lado, uma leitura das ocorrências do mesmo tipo no sector sueste do Atlântico Norte permite entender que estes fenómenos brutais constituem uma das características mais marcantes dos processos geomorfológicos que aí se verificam. As consequências destes processos apresentam quase sempre um carácter de catástrofe, o que, aparentemente, lhes confere características semelhantes aos casos conhecidos na Povoação.

Vejamos alguns casos recentes de precipitações elevadas ou de elevado número de mortos devidos a ocorrências desse tipo noutras áreas do sector sueste do Atlântico Norte(2):

- 12 de Novembro de 1950, Izaña (Tenerife), $428 \mathrm{~mm}$,

- 23 de Outubro de 1955, Izaña (Tenerife), $350 \mathrm{~mm}$,

- 6 a 12 de Novembro de 1950, Pico do Areeiro (Madeira), $349 \mathrm{~mm}$ em 3 dias,

- 4 de Novembro de 1956, Madeira, 30 mortos,

- 20 de Janeiro de 1979, Madeira, 12 mortos,

- 5 a 8 de Novembro de 1969, Faial (Açores), 150 $\mathrm{mm}$ (ao nível do mar), $620 \mathrm{~mm}$ (topo da ilha),

- 3 de Setembro de 1976, Açores, 68 mortos,

- 25/26 de Novembro de 1967, região de Lisboa, $158,7 \mathrm{~mm}$ no Monte Estoril (das $10 \mathrm{~h}$ do dia 25 às 10 h do dia 26), aproximadamente 500 mortos,

- 19 de Novembro de 1983, região de Lisboa, 7 mortos.

\subsection{Enquadramento físico e povoamento}

A bacia da Povoação corresponde a uma caldeira de abatimento esventrada a sul. O limite da bacia hidrográfica corresponde, grosso modo, ao rebordo da caldeira. As rochas vulcânicas que constituem o rebordo foram erodidas a sul, permitindo que o escoamento se faça para o mar. No entanto, esta abertura faz-se por uma estreita passagem para onde converge toda a drenagem da bacia hidrográfica. É nesse local, próximo do mar, que se situa a vila da Povoação.

A ilha de S. Miguel começou a ser povoada no século XV e o sítio da actual vila da Povoação foi o local escolhido para a primeira fixação de pessoas chegadas do continente (J.M.SANTOS, 1987). Sendo um local abrigado e com fracos declives, constituiu uma da primeiras opções dos continentais. Com o avanço do povoamento e o arroteamento de novas terras para o interior da bacia hidrográfica, começou a ocupação das áreas mais elevadas, mas de menores declives, as chamadas "Lombas". A subida para altitudes mais elevadas, bem mais favoráveis do ponto de vista da protecção em relação às catástrofes naturais, não significou, todavia, um abandono das áreas baixas da bacia hidrográfica, junto à foz.

Por outro lado, a ocupação da ilha estendeu-se a outros núcleos. Verificou-se a expansão para locais com relevo menos acidentado e de fácil acesso ao litoral. Desta forma, tornou-se importante a facilidade de comunicação com as novas localidades. A via marítima continuava a ser a forma mais fácil e rápida de estabelecer o contacto, apesar de estar dependente das condições climáticas do momento. Este facto determinava que a ocupação da área baixa da bacia hidrográfica da Povoação deveria continuar, sobretudo no respeitante às actividades comerciais e de serviços.

O coberto vegetal da ilha de S. Miguel sofreu uma grande evolução à medida que progredia o povoamento. Desde o século XV que se introduziram novas espécies, derrubaram florestas e se alargaram os campos de cultivo. Não é de estranhar que a vegetação natural ocupe hoje uma fraca extensão em toda a ilha. Na bacia da Povoação fez-se igualmente sentir essa evolução. Uma parte considerável da bacia hidrográfica é tida como de média a boa aptidão para a prática da agricultura. Em toda a área das "Lombas" é praticada a agricultura, embora predomine largamente o pasto. Só ficam livres de pasto os encaixes vigorosos dos cursos de água, as áreas de montanha com muito forte declive (junto dos interflúvios) e as áreas ocupadas pelos aglomerados populacionais. Nos primeiros, domina o mato (algumas áreas correspondem a sectores restritos de vegetação natural da ilha) e a floresta de criptomérias (Cryptomeria japonica, nativa da China e do Japão), árvores importadas quandodo povoamento da ilha e de fácil difusão e crescimento. 
A bacia hidrográfica foi sendo progressivamente ocupada pelas práticas agrícolas, que eram muito diversificadas, segundo as necessidades de auto-suficiência, do comércio e de posto abastecedor de navios. Estes factos impunham a lavra periódica dos terrenos, o que contribuia para infiltração das águas da chuva, apesar do substrato rochoso ser, por vezes, pouco permeável (formações de materiais piroclásticos muito finos).

Paralelamente, a lenha, recolhida ao longo das ribeiras fortemente encaixadas, era a fonte de energia utilizada. Isso permitia que os cursos de água estivessem sempre limpos de materiais susceptíveis de serem transportados ao longo dos canais de escoamento.

Apesar de haver condições naturais para a ocorrência de escoamentos de tipo torrencial, é provável que a frequência com quese verificava este tipo de processos não fosse a mesma da actualidade. Voltaremos a este ponto mais adiante.

Ao mesmo tempo que se procedia à ocupação da parte superior da ilha, desenvolvia-se o alargamento da área construída da vila da Povoação. Progressivamente, foi sendo ocupada toda a superfície quase plana que resultou da acumulação dos materiais transportados pelas diversas ribeiras que nela convergem, ou seja grande parte do cone de dejecção deste complexo mecanismo torrencial que drena toda a caldeira.

Como alargamento e evolução das áreas ocupadas, sobretudo no cone de dejecção, foi-se reduzindo a área disponível para a dinâmica flúvio-torrencial. Procedeu-se à canalização dos leitos fluviais, construíram-se pontes, estreitaram-se canais e ocuparam-se as áreas próximas dos estrangulamentos desses canais. De uma forma geral, tanto na Povoação como na vizinha aldeia do Faial da Terra, os cones de dejecção foram sendo totalmente ocupados, o que condicionou a dinâmica torrencial dos canais. Assim, sempre que os cursos de água adquirem um escoamento torrencial não é possível a expansão dos canais e as casas e os equipamentos instalados são mais ou menos profundamente afectados.

\subsection{Características climáticas}

Os aspectos climáticos dos Açores têm sido abordados em vários trabalhos de geógrafos. Num dos mais antigos, Raquel S. BRITO (1955), referindose ao anticiclone dos Açores como factor determinante do clima das ilhas, afirma que as condições do estado do tempo vão estar predominantemente dependentes da sua localização.

"Pela variação da posição e da intensidade do Anticiclone, pode produzir-se uma série de variantes":

a) Com o anticiclone muito desenvolvido para oeste, "as massas de ar tropical marítimo que atingem os Açores são mais quentes e mais húmidas, dando estratos baixos, chuviscos e por vezes nevoeiro: são as condições do tempo abafado e depressivo que ocorre por vezes".

b) Com o anticiclone centrado a sueste do arquipélago, este é invadido por "massas de ar com características próximas das do ar tropical marítimo", que provocam ainda a formação de estrato-cúmulos e de cúmulos que se resolvem em chuva.

c) Com o anticiclone centrado a noroeste, as massas de ar polar marítimo frio que invadem o arquipélago provocam a formação de "cúmulos grossos, estrato-cúmulos e aguaceiros" (p. 54-55).

Quando o anticiclone está centrado mais a sul e tem menor intensidade, o arquipélago fica sob a acção das depressões vindas de oeste, a que se associam, com muita frequência, frentes frias, que afectam mais ou menos o estado do tempo conforme a sua trajectória e velocidade; as ilhas ocidentais são as que mais sentem esta influência, que se traduz por períodos de mau tempo, com chuvadas fortes e ventos intensos de oeste.

Segundo a mesma Autora, as condições do estado do tempo vão depender do equilíbrio entre este conjunto de massas de ar, do seu contacto e da deslocação ao longo do Atlântico. No entanto, a importância que estes movimentos adquirem pode ser reforçada pela acção da topografia das ilhas. No que se refere a S. Miguel, a importância da topografia está bem patente na distribuição das precipitações. Essa distribuição faz-se de acordo com a topografia: dois maciços chuvosos separados por uma zona de mais fraca precipitação; aqueles correspondem aos maciços montanhosos, esta à plataforma da bacia de Ponta Delgada (p. 59).

Em 1980, Denise Brum FERREIRA desenvolveu um estudo sobre o clima das ilhas centrais dos Açores que se revelou essencial para entender o contexto climático regional em que se inserem as diversas ilhas do arquipélago. Este trabalho incide, no pormenor, sobre o grupo central das ilhas do arquipélago. No entanto, quando se trata de analisar o conjunto de tipos de tempo que afectamo arquipélago, é possível entender que a sua influência se estende ao grupo oriental.

As cheias rápidas em S.Miguel estão directamente relacionadas com diversos tipo de tempo que influenciam as precipitações no arquipélago dos Açores. Com efeito, D. B.FERREIRA (1980) estudou aqueles que condicionam o vento e a humidade das ilhas centrais do arquipélago dos Açores na estação fresca, tendo concluído pela classificação em tipos de tempo chuvosos de oeste, borrascas de sudoeste e tipos de tempo chuvosos frescos ou frios.

Embora as ilhas centrais distem mais de $100 \mathrm{~km}$ da ilha de S.Miguel, do conjunto de tipos de tempo 
que afectam o arquipélago na estação fresca, as borrascas de sudoeste e os tipos de tempo chuvosos de oeste, parecem determinar as condições para a ocorrência de processos geomorfológicos flúvio-torrenciais que se verificam no grupo oriental.D. B. FERREIRA (1980), referindo-se às correntes de sudoeste, afirma que, em casos extremos, “....a frente fria pressiona o sector quente; o que provoca uma muito forte instabilidade convectiva, com chuvas diluvianas e grandes tempestades" (p. 290).

Ainda no mesmo trabalho, a Autora apresenta o factor orográfico como sendo determinante no agravamento das condições que determinam a ocorrência de precipitações muito intensas: "Não é senão quando a vertente oriental do vale de altitude sobe o arquipélago que a instabilidade baroclínica do ar cresce, as núvens cumuliformes aparecem e as tempestades tornam-se copiosas. Em tipo (de tempo) de sudoeste, os relevos são em geral muito atingidos pela precipitação porque a ascendência forçada ao longo das vertentes arrefece rapidamente este ar fortemente carregado de humidade"(idem, p. 305). Esta influência do relevo para com a distribuição geográfica das precipitações é, assim, tornada mais explícita quando analisamos as correntes de sudoeste. A velocidade das massas de ar na baixa atmosfera é elevada. Ao atingir as ilhas, verifica-se uma subida drástica da massa de ar húmido, originando uma forte condensação. Ao contrário das massas de ar de $\mathrm{N}$ e NE, mais secas, as massas de ar de circulação de SW parecem ter uma influência determinante no desencadeamento de situações de crise, sobretudo na vertente sul das ilhas. Devemos salientar que a ilha de S. Miguel, no sector oriental, apresenta grandes desníveis topográficos, chegando mesmo a atingir os $1103 \mathrm{~m}$ de altitude (Pico da Vara).

Este tipo de análise parece coincidir com as descrições feitas para as cheias rápidas de 14 de Dezembrode 1996. Os diversos testemunhos coincidem na afirmação de que a deslocação rápida da massa de ar se fazia de sul para norte, com intensidade de precipitação muito forte. Parece, portanto, que a situação meteorológica que originou as cheias rápidas de Dezembro de 1996 se enquadra nos "tipos de tempo associados às correntes perturbadas de sudoeste" e que "têm todos um ponto comum : a sua violência pluviométrica" (D.B.FERREIRA, 1980).

Na cheia de 2 de Setembro de 1986, a situação meteorológica que condicionou o estado do tempo à superfície parece ter sido influenciada por uma depressão que estacionou sobre o arquipélago e que apresenta as características de uma gota de ar frio (F. REBELO e A. RAPOSO, 1988). Já em 1985, D.B. FERREIRA havia afirmado que se tornam muito importantes, "entre Setembro e Novembro, igualmente com trajectórias de sul e de sudoeste, as depressões frias regeneradas por ciclones tropicais provenientes das Antilhas, que passam pelos Açores. Estas depressões têm sempre um sistema nubloso turbilhonar compacto onde dominam os cúmulonimbos. Provocam fortes tempestades no mare chuvas copiosas ao passar pelas ilhas" (D. B. FERREIRA, 1985, p. 36).

O presente trabalho não tem por objectivo o estudo das condições meteorológicas e dos diversos tipos de tempo que condicionam os processos geomorfológicos ao nível das ribeiras. No entanto, fica claro que é fundamental o desenvolvimento desse estudo para compreender as condições de ocorrência das cheias mais recentes (de 2 de Setembro de 1986 e 14 de Dezembro de 1996). Será, então, possível chegar a uma tipologia de situações meteorológicas e tipos de tempo que poderão afectar a ilha de S. Miguel e condicionar o escoamento nos cursos de água e sistemas flúvio-torrenciais. Só assim poderá ser desenvolvido um sistema de previsão das situações de crise que eventualmente afectarão a ilha de S. Miguel. Tal estudo não é desenvolvido aqui, mas, no âmbito de um esquema de protecção civil, não deverá ser ignorado.

\subsection{As cheias de 1986 e 1996}

As cheias de 1986 e 1996 são as que permanecem mais vivas na memória das populações. Para isso, muito contribuíram dois factos: são recentes eccorreram com um intervalo de tempo curto (dez anos), o que torna inevitável a comparação.

As características da cheia de 2 de Setembro de 1986 foram descritas por F. REBELO e A. RAPOSO (1988). A dificuldade de obtenção de dados meteorológicos para 1986 foi então referida. Já nessa altura se verificou que os udómetros avariaram ou foram inundados devido à grande quantidade e intensidade da precipitação. Os valores que se recolheram não correspondem à totalidade de precipitação ocorrida. Dez anos depois, não tinham sido repostos os udómetros avariados, o que torna ainda mais difícil a caracterização do tipo de precipitação que originou este tipo de escoamento.

No entanto, para o caso das cheias de 14 de Dezembro de 1996, é possível verificar que os diversos testemunhos são coincidentes em referir grande quantidade de precipitação num curto período de tempo. Nas Furnas, a oeste da Povoação, foi possível verificar uma precipitação de $33 \mathrm{~mm}$ em cerca de 13 minutos. No dia 15 de Dezembro, o udómetro da Lagoa das Furnas registava $90,6 \mathrm{~mm}$. Nos dias 13 e 14 a precipitação tinha sido, respectivamente, de 0 e $1 \mathrm{~mm}$. Até ao dia 7 , praticamente não choveu. Desde o dia 7 até ao dia 12, os valores registados foram de 7.1, 22.3, 14.5, 
25.2 e $26.2 \mathrm{~mm}$. A humidade relativa, tanto do mês de Novembro como do mês de Dezembro, foi sempre elevada. Com frequência atingiu os $90 \%$. No dia 13 foi de $93 \%$, no dia $14,95 \%$ e no dia $15,98 \%$.

Tanto em 1986, como em 1996, o aspecto torrencial do escoamento parece sobressair do conjunto das descrições feitas. F. REBELO e A. G. B. RAPOSO (1988) salientaram alguns elementos essenciais das cheias de 1986: o trabalho de sapa nos canais de escoamento, sobretudo nas margens côncavas, o escoamento superficial e a criação de ravinamentos, tal como a ocorrência de deslizamentos nas vertentes muito declivosas das cabeceiras de linhas de água. Este conjunto de processos geomorfológicos verificou-se, de igual forma, nas cheias de 1996. No que se refere às consequências das cheias, voltamos a encontrar uma grande semelhança entre os dois acontecimentos. As ruas inundadas, as estradas destruídas nas margens dos canais de escoamento, pontes destruídas ou danificadas, canais de escoamento assoreados.

Há, portanto, uma grande semelhança de processos geomorfológicos e de consequências sobre os diversos equipamentos instalados nos leitos de inundação.

\section{Factores gerais que condicionam a ocorrência de cheias}

\subsection{Litologia}

Se em qualquer bacia hidrográfica a litologia representa um dos factores mais importantes para explicar o comportamento da água, no caso da bacia da Povoação essa importância é acrescida. As formações de cobertura que ocupam quase toda a área da depressão da Povoação são constituídas essencialmente por cinzas vulcânicas conferindo-lhes uma textura de tal forma fina que quase não permitem a infiltração das águas. Junto à linha divisória de águas, afloram algumas rochas vulcânicas (andesitose andesitos peridotíticos) que apresentam uma disposição estrutural muito próxima da horizontal. Estas rochas alternam com materiais de projecção finos e desagregados o que coloca os afloramentos numa posição de fraqueza em relação aos processos erosivos de evolução de vertente.

Mais perto do centro da depressão, essa alternância mantém-se e a disposição das bancadas é horizontal ou com fraco pendor, para sul. No sector das "Lombas", ao longo dos encaixes das ribeiras, afloram bancadas de traquitos e latitos, sob a espessa cobertura de materiais de projecção. É a dureza daqueles afloramentos que permite a conservação do vigor das vertentes dos encaixes em gargantas e canhões das várias ribeiras que constituem a bacia hidrográfica da Povoação. O vigor das vertentes que limitam o cone de dejecção, junto à vila da Povoação, é assegurado pela dureza destas bancadas. Ainda aflora, no sector norte da bacia hidrográfica (Pico da Vara), o complexo basáltico do Nordeste, com uma espessura próxima dos $300 \mathrm{~m}$.

\subsection{Morfologia}

Da morfologia da bacia hidrográfica da Povoação destacam-se quatro sectores distintos: as vertentes abruptas perto da linha divisória de águas, a superfície das 'Lombas', o encaixe da rede de drenagem imediatamente a montante da vila da Povoação e a planície de inundação (na prática um autêntico cone de dejecção) das ribeiras que confluem na Povoação.

\section{As vertentes abruptas perto da linha divisória de águas}

De uma forma geral, este conjunto de vertentes corresponde aos rebordos da antiga caldeira vulcânica que abateu e ficou limitada pelas paredes do vulcão entretanto inactivo. No entanto, essa coincidência não é perfeita. No sector nordeste, o encaixe da rede de drenagem no rebordo permitiu o alargamento da bacia hidrográfica para além dos limites da caldeira vulcânica. Esse encaixe faz-se ao longo de fracturas, a expensas de materiais vulcânicos duros. Torna-se um encaixe vigoroso dada a facilidade com que a rede de drenagem utiliza a fracturação, mas o facto das vertentes serem talhadas em intercalações de rocha mais dura e de rocha menos dura permite-lhes conservar os declives fortes.

\section{A superfície das "Lombas"}

Entre as vertentes abruptas junto aos limites da bacia hidrográfica e até próximo do mar, estende-se um relevo de fracos declives, melhor conservado a montante (estrada do Simplício), mas profundamente entalhado pelos cursos de água mais importantes a jusante ("Lombas" junto à Povoação). Nestes sectores, a superfície das "Lombas" já não é reconhecida a não ser por interflúvios estreitos e alongados, até que desaparecem com a confluência das várias ribeiras junto à Povoação. Esta superfície, hoje praticamente desmantelada, deverá ter constituído um nível de base do escoamento da própria depressão.

\section{O encaixe da rede de drenagem imediatamente a montante da vila da Povoação}

No processo de desmantelamento da superfície das "Lombas", desenvolveram-se os encaixes da rede de drenagem que originaram gargantas e canhões. Esta morfologia parece ser determinante no desenvolvimento de toda a dinâmica de drenagem. 
Esse encaixe processou-se de forma mais vincada nos canais de escoamento de maior dimensão (Ribeiras do Purgar e dos Lagos), mas foi mais difícil nas ribeiras mais pequenas (Ribeiras dos Bispos e Poiso dos Pombos). Estas acabam por atingir a área mais baixa (junto da Povoação) por canhões suspensos sobre o vale das restantes ribeiras. Neste sector, a dinâmica flúvio-torrencial adquire um novo impulso, mesmo a montante das áreas mais densamente povoadas.

\section{A planície de inundação das ribeiras que confluem na Povoação}

Esta área corresponde à área de confluência das várias ribeiras e é constituída pela acumulação de sedimentos. Neste sector, o vale, resultado do encaixe conjunto da rede hidrográfica, alarga-se e apresenta um fundo plano, fácil de ocupar pelas populações que iniciaram a ocupação da ilha.

\subsection{Declives}

A distribuição dos declives na bacia da Povoação faz-se por duas áreas bem distintas. Uma das áreas mais declivosas situa-se junto às cabeceiras das linhas de água. Com declives que rondam os $30^{\circ}$, estas áreas apresentam, no entanto, largos sectores em que a inclinação da superfície topográfica atinge os $50^{\circ}$. Outros sectores com declives igualmente importantes são os encaixes dos cursos de água na superfície das "Lombas". Estes encaixes conservam vertentes abruptas, quer a expensas de rochas duras, quer devido à acção dos cursos de água com trabalho de sapa na base das margens côncavas. Quanto mais próximo da confluência das várias ribeiras, maior é o encaixe, bem como os declives.

Entre os vales encaixados, existem interflúvios com declives fracos que são utilizados para pastagens. Estes parecem corresponder a uma superfície que terá constituído o fundo da caldeira de abatimento. Uma vez aberta a caldeira, a sul, esta superfície foi sendo entalhada pela rede de drenagem, respondendo ao apelo dum novo nível de base mais baixo. Os declives fracos voltam a estar presentes junto ao mar, na área de convergência dos vários canais de escoamento. Nesta área, o apelo do nível de base deixa de se fazer sentir e a erosão dá lugarà deposição, o que confere o aspecto pouco declivoso do sítio da vila da Povoação.

\subsection{Morfometria da bacia hidrográfica}

A bacia da Povoação tem uma área de cerca de $31,7 \mathrm{Km}^{2}$ e um perímetro de $25,5 \mathrm{Km}$, com uma amplitude altimétrica de $1103 \mathrm{~m}$ e uma integral hipsométrica de 0,36 , o que lhe confere uma altura média relativamente baixa de $397,1 \mathrm{~m}$. Podemos considerar que a altura média é relativamente baixa tendo em consideração a amplitude altimétrica, o que nos permite dizer que uma parte considerável do relevo se encontra a altitudes baixas, embora o desnível entre os interflúvios e a foz seja extremamente forte. Por outro lado, a densidade de drenagem é de 5,3 $\mathrm{Km} / \mathrm{Km}^{2}$ o que não constitui um valor muito elevado. De facto, A. N. STRAHLER (1979) refere como densidade de drenagem fraca valores da ordem de 3 a $4 \mathrm{Km} / \mathrm{Km}^{2}$ e valores de 12 a $16 \mathrm{Km} / \mathrm{Km}^{2}$ para densidades médias, considerando elevada a densidade de drenagem superior a de 30 a $40 \mathrm{Km} / \mathrm{Km}^{2}$.

Apesar do conjunto de materiais com características pouco favoráveis à infiltração, a escorrência concentrada parece não ser determinante na morfogénese desta bacia hidrográfica. O encaixe da rede hidrográfica parece privilegiar as linhas de água já constituídas, alargando as margens, aprofundando os fundos, mas dificilmente se procede à formação de novas linhas de água. Da mesma forma, com uma fraca densidade de drenagem, o escoamento e a concentração dos picos de cheia deveria ser dificultado pelo número diminuto de canais de escoamento. Se existe um rápido escoamento ao longo da bacia hidrográfica, não pode ser atribuído à escorrência concentrada mas, talvez, à escorrência difusa ou de fraco encaixe ao longo das vertentes. A atenção a ser dada à escorrência difusa e ao ravinamento de pequena profundidade parece ser importante para oentendimento da rapidez da ocorrência das inundações na vila da Povoação.

A bacia hidrográfica da Povoação pode ser considerada circular. Com um índice de circularidade de 0.61 (para um máximo de 1) a concentração da drenagem é extremamente facilitada. De facto, o local de confluência das ribeiras é só um - a vila da Povoação. É normal que, quando ocorre um episódio chuvoso, a onda de cheia atinja, em simultâneo, a área onde se localiza a Povoação. Apesar da precipitação se poder dispersar pelas bacias hidrográficas das várias ribeiras, a concentração é inevitável dado o elevado índice de circularidade.

\subsection{Coberto vegetal}

Uma parte considerável da bacia hidrográfica da Povoação é ocupada por pastagens para gado bovino. Nas áreas mais planas não existe outro tipo de cobertura vegetal já que a criação de gado domina grande parte da economia agrária da ilha. A bacia da Povoação não é excepção no conjunto da ilha de S. Miguel.

Nas áreas mais declivosas, onde a utilização 
agrícola é praticamente impossível, domina a floresta de criptomérias (Cryptomeria japonica) que é, em geral, muito densa, bem como a vegetação natural e o mato. Os sectores onde a floresta de criptomérias é mais abundante situam-se junto ao limite da bacia hidrográfica e nos encaixes da rede de drenagem.

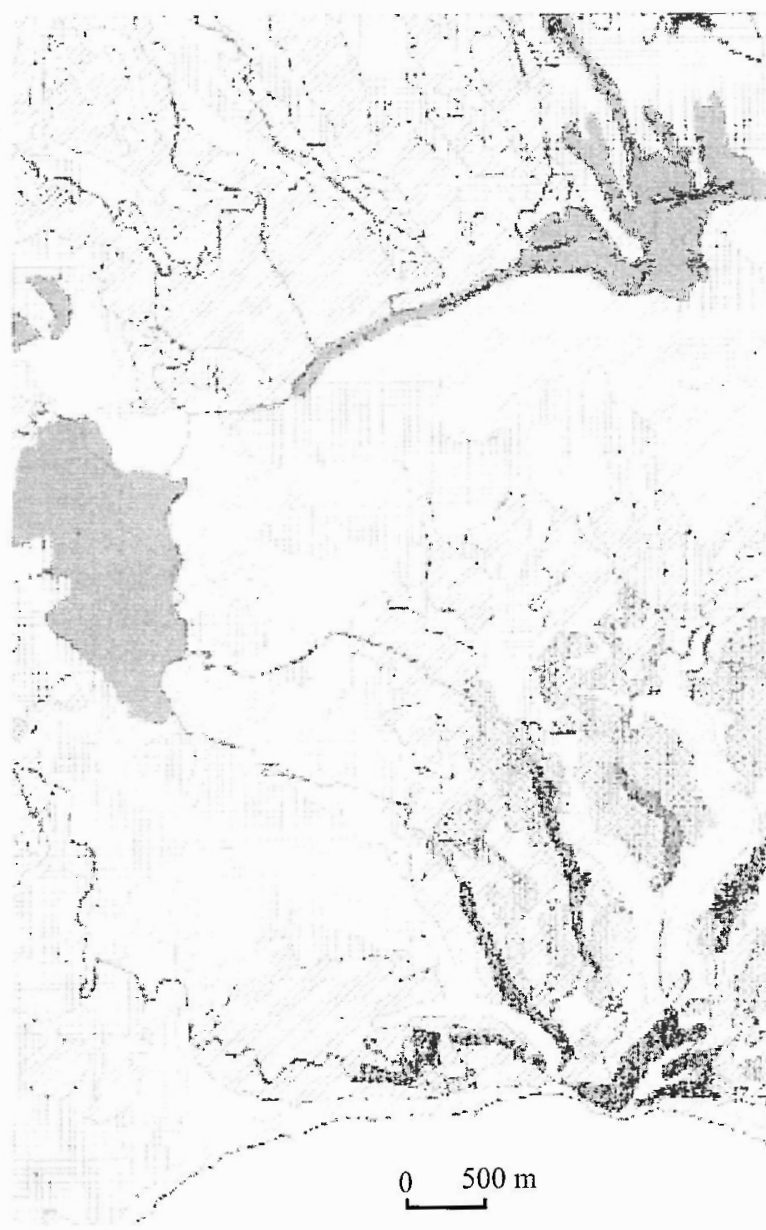

\section{LEGENDA}

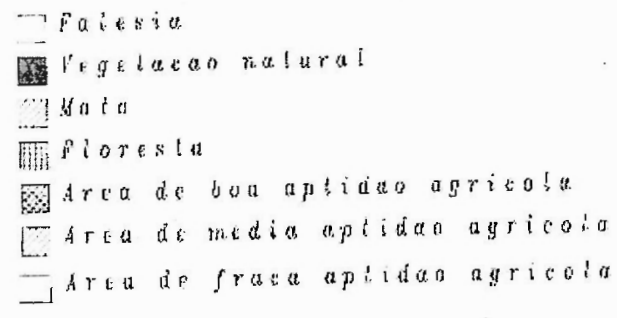

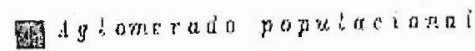

$$
\text { Parto e purtinha }
$$

ARsiratas

\subsection{Factores antrópicos}

Nas últimas décadas, a criação de gado bovino constituiu-se na principal actividade económica, o que transformou em pasto uma área considerável da bacia hidrográfica. As práticas agrícolas que promoviam
Fig. 1 - Plano Director Municipal (Povoação). extracto da carta de diagnóstico

a lavra dos terrenos foram abandonadas e o alargamento dos pastos a expensas das áreas florestadas foi incrementada. Este facto é apontado como sendo um factor determinante das cheias. No entanto, a criação de gado sóse generalizou verdadeiramente nos últimos 30 a 40 anos, o que até parece contraditório com o facto de haver notícias de cheias desde o século XVIII (1744). Poderá, no entanto, constituir parte da explicação para o facto de, mais recentemente, a frequência de ocorrência ser maior.

Por outro lado, a ocupação humana dos leitos de inundação representa uma forte vulnerabilidade em quaisquer cursos de água. Quando estes convergem para o mesmo vale, o risco é acrescido. De facto, na vila da Povoação, para além da ocupação total do 
leito de inundação, procedeu-se à construção de uma estrada sobre o leito menor da ribeira de Poiso das Pombas, desde o parque zoológico até ao mar. Sabendo-se que a velocidade de escoamento diminui com o atrito das paredes do canal, criaram-se condições para uma maior concentração do pico de cheia e consequente transbordo para a planície de inundação na área imediatamente a montante da canalização (Rib ${ }^{\mathrm{a}}$ de Poiso dos Pombos - parque zoológico).

\section{Os processos erosivos nas vertentes}

As vertentes mais declivosas situam-se próximo dos limites da linha divisória de águas e ao longo dos encaixes vigorosos dos canais de escoamento mais importantes. Nestes sectores, os declives rondam valores iguais ou superiores aos $30^{\circ}$, chegando mesmo a atingir valores próximos dos $50^{\circ}$. Para além disso, estas vertentes estão densamente florestadas e o substrato rochoso é constituído por materiais de projeç̧ão que têm uma forte componente argilosa e uma espessura que pode atingir as centenas de metros $(400 \mathrm{~m})$.

Nas condições referidas é fácil de aceitar que, na bacia hidrográfica da Povoação, à semelhança do que ocorre na parte ocidental da ilha, os processos geomorfológicos de evolução de vertentes mais importantes sejam, a par dos ravinamentos, os movimentos em massa.

\subsection{Os movimentos em massa}

É possível verificar inúmeras cicatrizes de diversos movimentos em massa, dos quais se destacam, pelo seu número, os deslizamentos peliculares. Estes são de pequena dimensão (cerca de 20 a $30 \mathrm{~m}$ de largura) e a sua espessura raramente atinge valores superiores a 1 metro. No entanto, são muito numerosos e, por isso, afectam uma extensa área nas cabeceiras das linhas de água. A infiltração é ainda facilitada pelo papel da vegetação que ocupa largos sectores dessas cabeceiras, sob a forma de vegetação arbustiva e de floresta. Desta forma, estão reunidas as condições mais favoráveis para o desenvolvimento de processos erosivos deste tipo. A quantidade de materiais erodidos é elevada promovendo a alimentação das linhas de água em carga sedimentar abundante e de dimensão muito diversa. As argilas que constituem as formações de material de projecção, conjuntamente com os calhaus e blocos de rochas vulcânicas, deslizam e atingem as linhas de água que, devido aos elevádos declives dos perfis longitudinais, funcionam como corredores de evacuação rápida dos materiais.

No Faial da Terra (a leste da Povoação) é possível identificar um processo de evolução de vertentes muito semelhante a um gigantesco fluxo de detritos que, de certa forma, associa numa única unidade geomorfológica o conjunto de processos já referidos (fig. 1). Tudo indica que a Ribeira do Faial da Terra, episodicamente, adquire as características de um

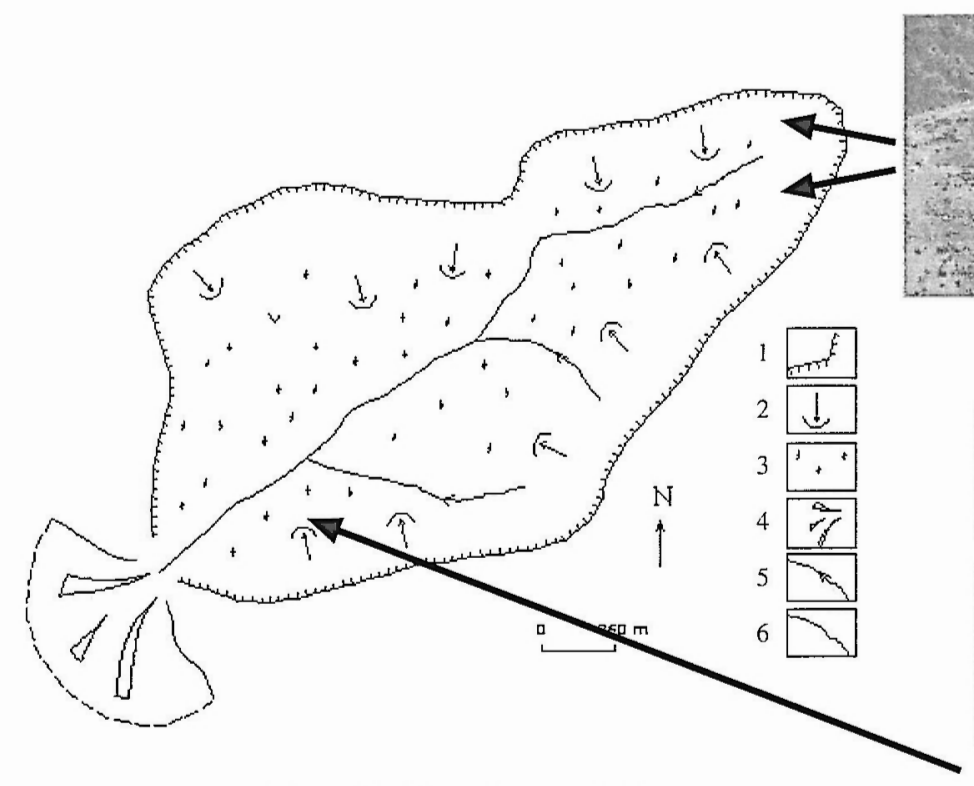

Fig. 1 - Eshoço geomorfológico da Ribeira da Grota do Pico,

Faial da Terra. 1 - Limite da bacia de recepção.

2 - Deslizamento. 3 - Escorrência.

4 - Cone de dejecção. 5 - Ravina. 6- Curso de água. 
escoamento torrencial. Apresenta, ao longo de todo o ano um escoamento fluvial que só se transforma em torrencial em situações meteorológicas extremas. É nessas alturas que se procede à mobilização dos materiais nas cabeceiras das linha de água (fot. 1). Esta faz-se por movimentos em massa, e não por escoamento superficial, ao contrário do que se verifica nas torrentes. Por outro lado, o conjunto da carga sedimentar transportada ao longo do canal de escoamento é constituído por blocos, calhaus, argilas, areias e material lenhoso (fot. 2). Apresenta, portanto, as características dos materiais transportados ao longo dos fluxos de detritos. Para que este escoamento se desenvolva, muito contribuem os elevados declives do perfil Iongitudinal da ribeira. Em 14 de Dezembro de 1996, ocorreram deslizamentos peliculares nas cabeceiras das linhas de água que rapidamente atingiram a localidade obstruindo pontes eprovocando o transbordo dos canais de escoamento. A catástrofe esteve eminente. Uma pequena ponte conseguiu reter grandes quantidades de materiais impedindo que atingissem as casas.
Para além dos deslizamentos peliculares, é possível ver, ainda nas cabeceiras das linhas de água, inúmeros fluxos de detritos de pequena dimensão (fot. 3 ). Estes movimentos em massa são constituídos por um sector de arrancamento onde se forma uma cicatriz, um extenso canal por onde se movimentam os materiais oriundos da cicatriz e uma área de acumulação junto da base da vertente. Em geral, essa área coincide com uma linha de água de primeira ordem, o que contribui para a remoção dos materiais movimentados pelo fluxo de detritos e/ou deslizamentos. Posteriormente, a evolução das formas resultantes destes processos faz-se por ravinamento intenso e profundo, conduzindo a processos erosivos muito para além da área inicialmente afectada pelo fluxode detritos. As vertentes junto à linha limite da bacia hidrográfica, que apresentam declives entre os $30^{\circ}$ e os $50^{\circ}$, estão sujeitas a uma acção erosiva muito forte, que só diminui com a proximidade dos afloramentos rochosos mais duros de basalto, andesitos e andesitos peridotiticos.

Fot. 3 - Fluxo de pequenas dimensões. Cabeceiras da bacia hidrográfica da Ribeira dos Pelames, junto à lixeira.

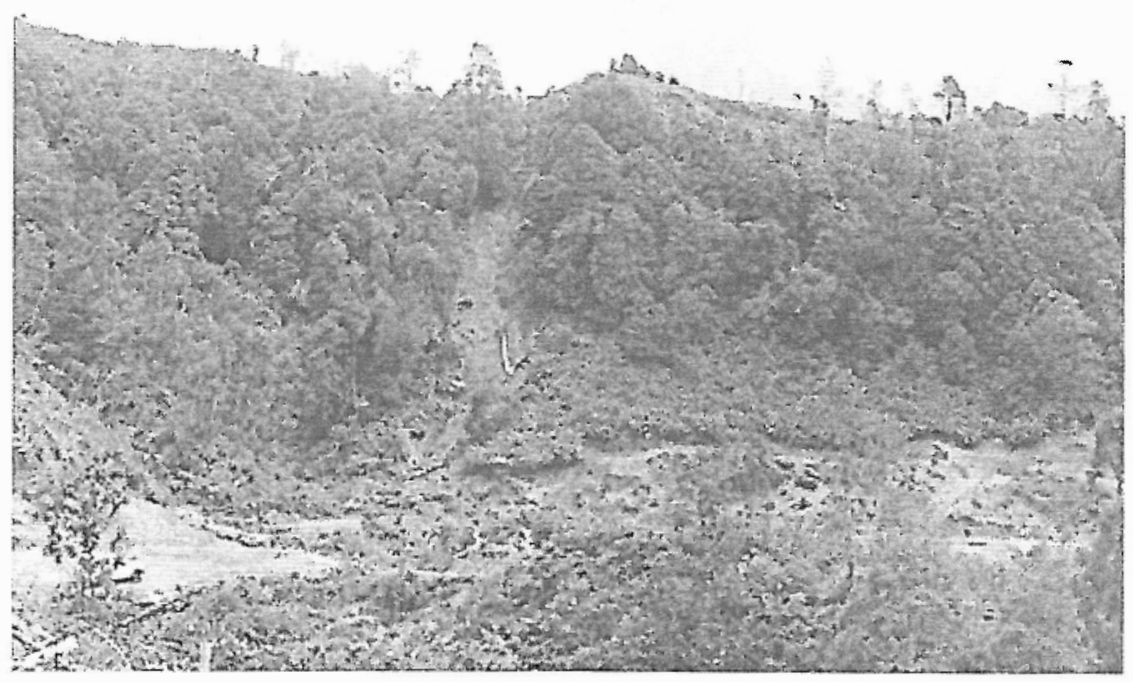

Nas Furnas (a oeste da Povoação), ocorreu um fluxo de detritos que parece elucidativo sobre um dos processos de evolução de vertentes característico da parte oriental da ilha de S.Miguel. O fluxo ocorreu a expensas dos materiais de projecção que, neste sector, são caracterizados pela alternância de materiais grosseiros e materiais finos, ambos de muito fraca coesão. Estes materiais dispõem-se próximo da horizontal e as vertentes apresentam densa cobertura florestal. Este facto facilita a infiltração e garante a saturação do substrato rochoso e a consequente perda de coesão dos materiais.

A cicatriz apresenta-se com a forma circular, de grande dimensões (cerca de 50 metros de altura e 80 metros de diâmetro) e de paredes quase verticais. A movimentação dos materiais escavou um canal de escoamento, nos materiais de projecção, com altura variável entre os 10 e os 15 metros, de paredes verticais, próximo da base da vertente, onde os declives são mais baixos $\left(12^{\circ}\right.$ a $\left.18^{\circ}\right)$. A área de deposição, que se estende por cerca de 500 metros, com largura máxima de 100 metros, atingiu os 8 metros de espessura em muitos sectores e destruiu todos os campos agrícolas ao longo do trajecto (fig. 3 e fot. 4 e 5 ).

A frente do fluxo ainda afectou o campo de futebol na parte superior da vila das Furnas. A movimentação dos detritos ocorreu por várias fases. A primeira movimentou a maior parte dos materiais 
Fig. 3 - Esboço geomorfológico esquemático do fluxo de detritos do Fojo. 1 - Área de acumulação. 2 - Canal de

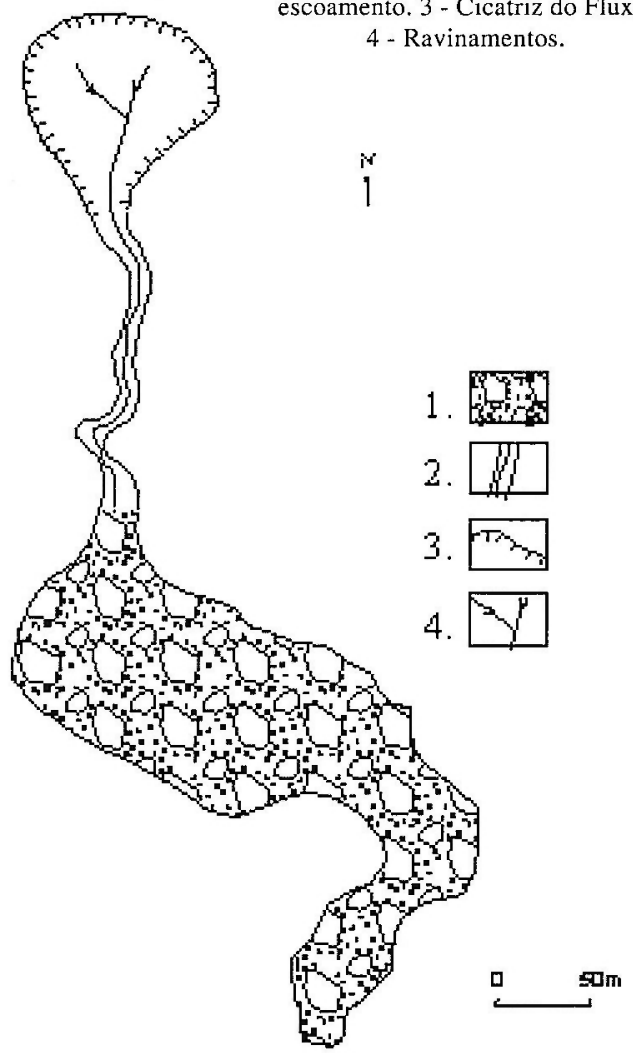

e criou o essencial da cicatriz; seguiram-se várias outras deslocações, com o consequente transporte de materiais. Posteriormente, a escorrência assumiu um papel importante permitindo o transporte de grandes quantidades de argila quer do local da cicatriz, quer dos materiais acumulados na base da vertente.

A morfologia final resultante do desenvolvimento do fluxo de detritos do Fojo tem todas as características de uma torrente. A parte da cicatriz apresenta a forma de uma bacia de recepção, desembocando por um canal de escoamento e terminando por uma área de deposição ao longo da Ribeira do Fojo. A provável evolução deste sistema continuará a fazer-se, antes de mais, por movimentações em massa que provocarão o recuo da cicatriz. Essas movimentações constituem a resposta à saturação dos terrenos a montante, onde a densa cobertura vegetal é predominante. Simultaneamente, desenvolver-se-ão processos erosivos relacionados com o escoamento superficial e proceder-se-á ao encaixe de linhas de água, sobretudo na área da cicatriz onde ocoberto vegetal foi totalmente destruído. Poderá dar-se o aumento da área da cicatriz e, portanto, haverá o natural alargamento da bacia de recepção do referido sistema torrencial. Este processo permitirá

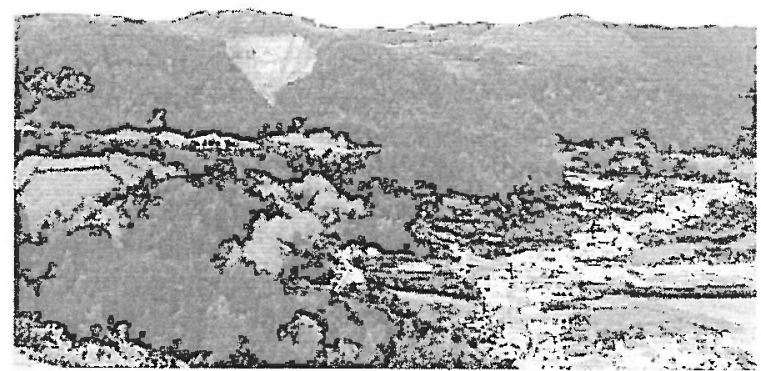

Fot, 4 - Vista geral das Furnas e cicatriz do fluxo do Fojo.

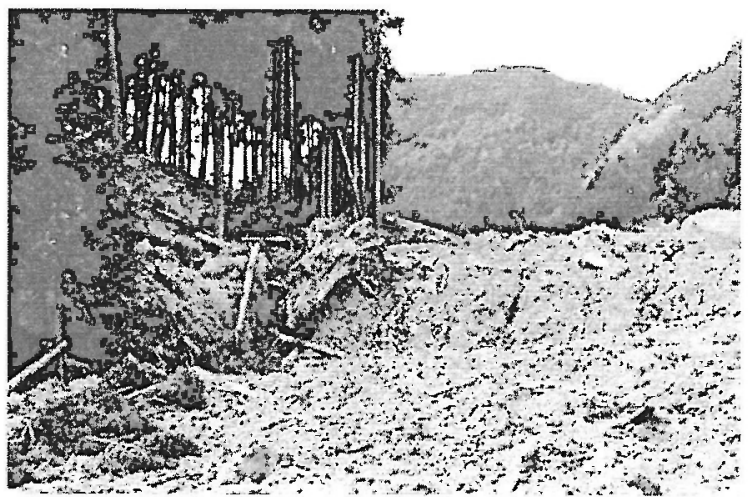

Fot. 5 - Materiais movimentados e acumulados no vale da Ribeira do Fojo.

a recolha de quantidades crescentes de água o que facilitará o encaixe da rede de drenagem. Progressivamente, todo o sistema de drenagem será ampliado. Poderá, assim, evoluir no sentido de constituir um sistema flúvio-torrencial, à semelhança do que parece ter ocorrido na Ribeira do Faial da Terra e seus afluentes.

No respeitante à bacia da Povoação, o sector dos encaixes da rede hidrográfica na superfície das "Lombas" é, sem dúvida, uma das áreas onde se verificam com mais frequência movimentos em massa. As bancadas de traquitos e latitos apresentam aí uma disposição muito próxima da horizontal e os encaixes dos cursos de água têm as características de gargantas e canhões. Quando a litologia é constituída essencialmente por materiais de projecção, o encaixe é facilitado e os vales adquirem o aspecto de gargantas. A evolução das vertentes torna-se muito rápida por efeito do trabalho de sapa intenso promovido pelos cursos de água. Nas margens côncavas dos meandros a acção erosiva é muito forte e os desmoronamentos e deslizamentos peliculares são os processos de evolução de vertentes mais importantes. Estes materiais caem directamente no leito dos canais de escoamento sendo de imediato removidos. Desta forma, o processo de meandrização 
é muito rápido propiciando uma carga sedimentar importante. Esta carga, constituída por calhaus, blocos, argila em abundância e muito material lenhoso, vai aumentar o poder abrasivo dos cursos de água e, por sua vez, intensificar a acção erosiva sobre as margens e fundo do canal (fot. 6).

\author{
Fot. 6 - Encaixe meandrizante na \\ superficie das "Lombas". \\ A evolução do meandro faz-se \\ por trabalho de sapa e deslizamento \\ na margem côncava.
}

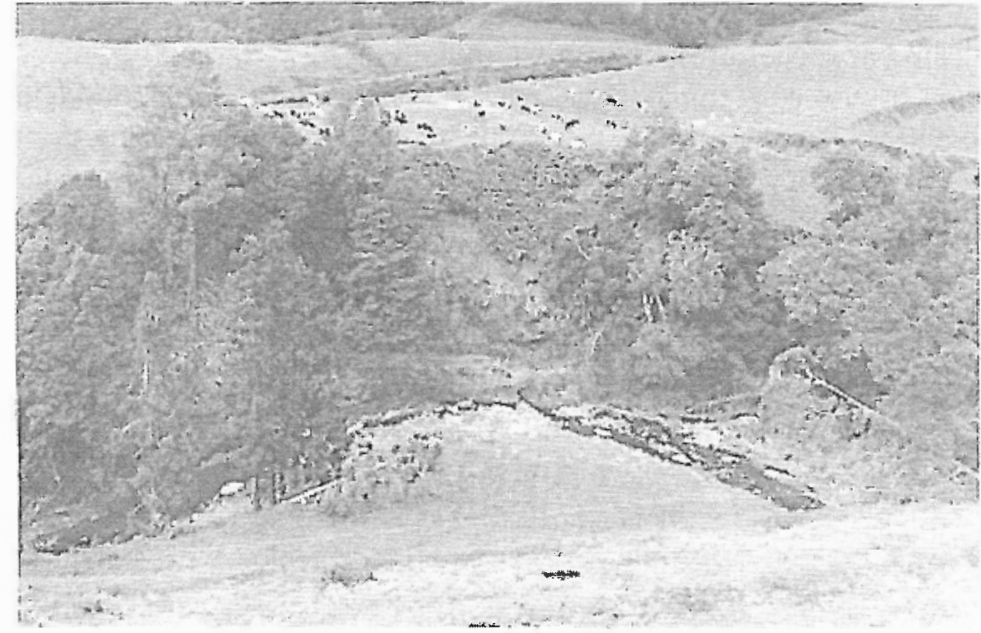

Na secção média da bacia da Povoação, os encaixes nos materiais de projecção são muito importantes (atingindo os 50 metros) e, por isso, grande parte da carga sedimentar que atinge a secção baixa da bacia hidrográfica (junto à vila da Povoação) é alimentada pelos materiais mobilizados por estes processos.

\subsection{Escorrência difusa e escorrência concentrada}

Na bacia da Povoação é possível verificar os efeitos do escoamento superficial sobre os solos.
Grande parte da área agrícola desenvolve-se na secção média da bacia hidrográfica, nos sectores onde os declives são menores (área das "Lombas"). Esses são intensivamente ocupados por pastos, cujas ervas servem de alimento aos animais (especialmente gado bovino). Os terrenos são compactados pelo pisoteio dos animais, o que dificulta a infiltração das águas das chuvas. Uma vez compactada a superfície dos terrenos, é fácil o desenvolvimento da escorrência, o que acelera a formação de ravinas (fot. 7,8 e 9).
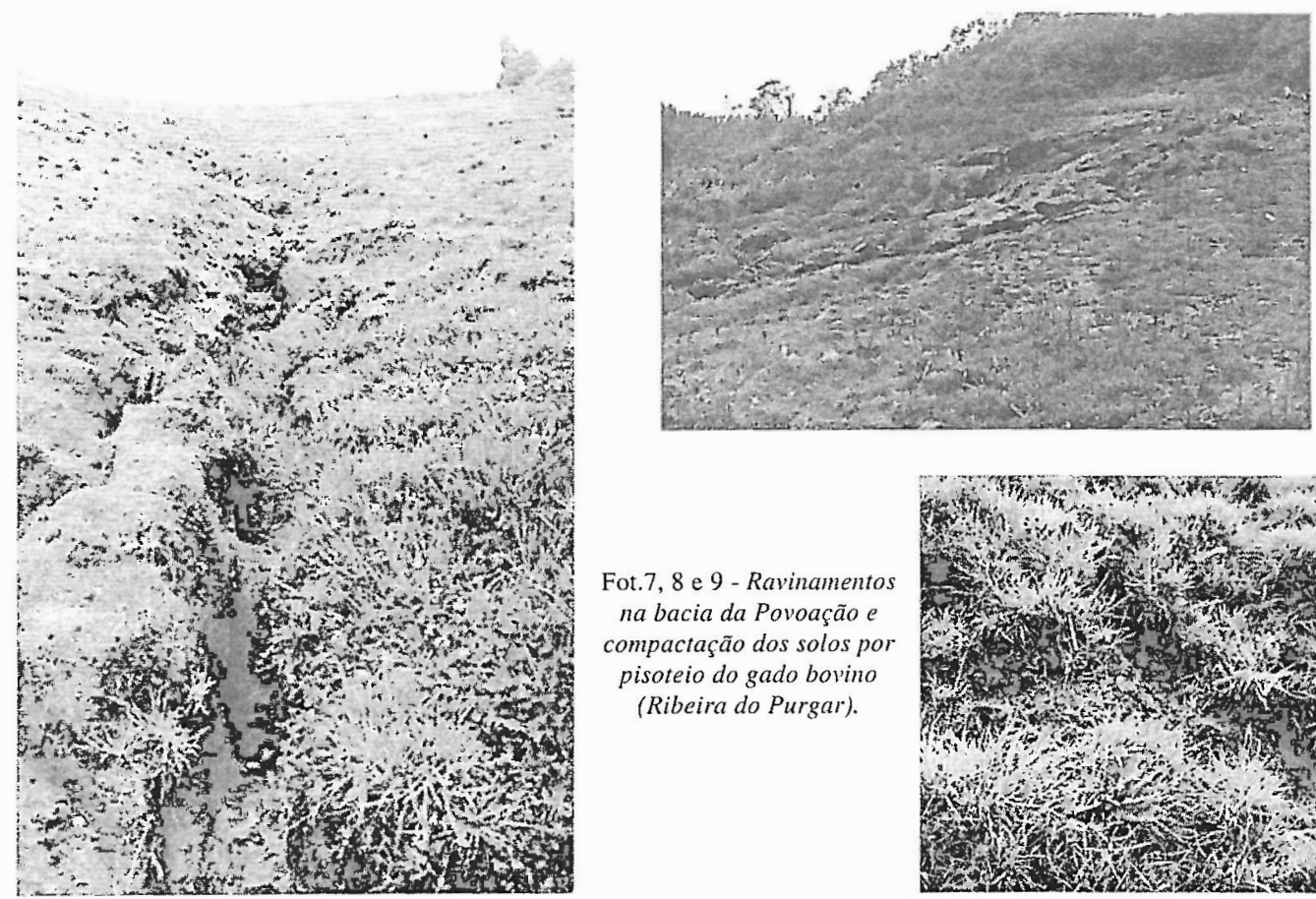

Fot.7, 8 e 9 - Ravinamentos na bacia da Povoação e compactação dos solos por pisoteio do gado bovino (Ribeira do Purgar).

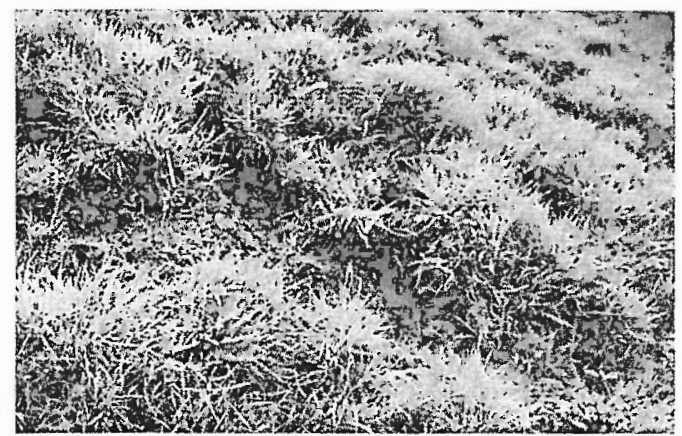


Outro dos factores determinantes na generalização do escoamento superficial a toda a bacia hidrográfica é a escorrência resultante da acção de terraplanagem, com o objectivo de conquistar, para o pastoreio, terrenos muito declivosos. Estes procedimentos destroem a cobertura herbácea, o que expõe as formações argilosas ao impacto das gotas da chuva sobre o solo, impede a infiltração e generaliza o escoamento superficial.

As práticas agrícolas têm permitido, nas últimas décadas, a compactação progressiva dos solos uma vez que a lavra foi praticamente abandonada. A lavra promovia o revolvimento das camadas superficiais dos solos e aumentava os espaços vazios, facilitando a infiltração. Uma vez que as pastagens estão desenvolvidas em terrenos de forte componente argilosa, é quase impossível a infiltração, o que permite a rápida movimentação das águas à superfície, que, assim, atingem facilmente os canais de escoamento. Apesar de uma densidade de drenagem fraca, a escorrência pelas vertentes conduz a um escoamento rápido da água.

\section{Os processos geomorfológicos nos canais de escoamento}

\subsection{Os "Conglomerados da Povoação"}

É possível verificar a existência de inúmeros vestígios de uma dinâmica fluvial com características torrenciais. Ao longo dos canais de escoamento, em áreas onde o perfil longitudinal apresenta um declive acentuado, o encaixe faz-se em materiais que constituem depósitos de espessura muito elevada (superando, com frequência, os $10 \mathrm{~m}$ ). Estes depósitos têm como característica fundamental a heterometria dos materiais que os constituem, disposição caótica e matriz argilosa abundante (fot.10). $\mathrm{O}$ aspecto boleado dos calhaus e blocos indicia transporte ao longo de distâncias pequenas. A matriz é constituída principalmente por argilas originárias das formações de cobertura que ocupam uma larga área da bacia hidrográfica. Os blocos e calhaus provêm das rochas vulcânicas que constituem o rebordo da cratera da Povoação.

De uma forma geral este tipo de depósito localizase, preferencialmente, próximo da base das grandes vertentes onde se encontram as cabeceiras das linhas de água. No entanto, é difícil perceber a diferença entre este tipo de depósito e os extensos depósitos de calhaus, blocos e areias que se encontram ao longo dos leitos das principais ribeiras que constituem a bacia da Povoação. Na secção superior da bacia hidrográfica, onde as ribeiras o entalham, apresenta grande espessura e heterometria, bem como uma matriz areno-argilosa abundante. Muito do material que é transportado nas situações de catástrofe natural que afectaram a vila da Povoação resulta da erosão deste depósito, que tem características torrenciais e é em tudo semelhante aos que resultaram dos episódios de 1986 e 1996, mas que se originou numa fase antiga em que o nível de base correspondia à superfície das "Lombas" (fot. 10 e 11).

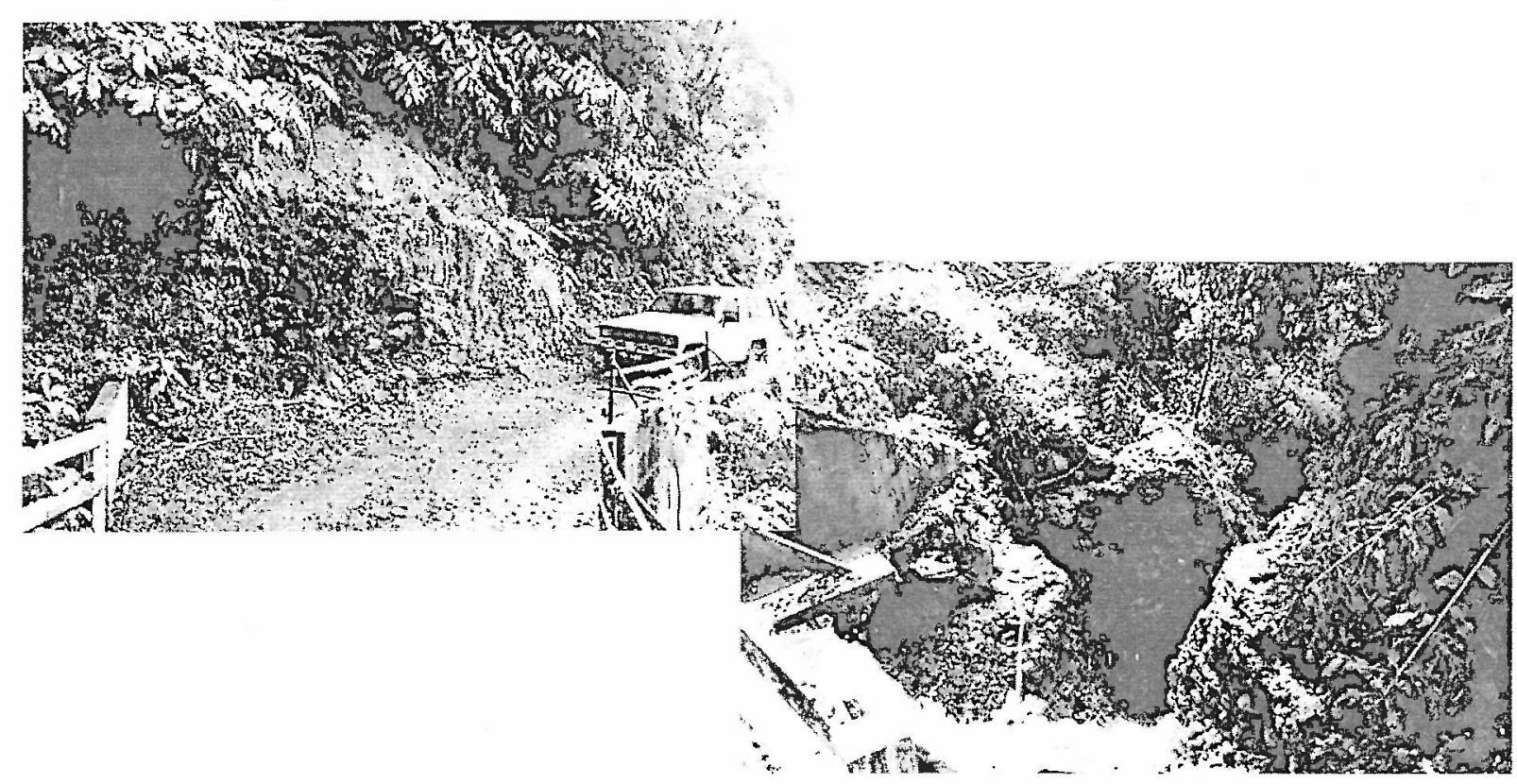

Fot. 10 e 11 - "Conglomerados da Povoação". A espessura destes depósitos chega a ultrapassar as dezenas de metros. Nestes sectores, o encaixe das ribeiras é profundo, mobilizando-se grande quantidade de sedimentos em tempo de cheia. 


\section{2. Áreas de erosão nos canais de escoamento}

Perto da Estrada do Simplício, a ribeira do Purgar encaixa-se profundamente (mais de $50 \mathrm{~m}$ ), quase que por completo num depósito com as características dos "Conglomerados da Povoação". O encaixe no depósito é interrompido no local da ponte uma vez que o leito está cimentado (Fig. 4/A, fot. 11). O escavamento, porém, prossegue sob a placa de cimento que se encontra parcialmente suspensa. Os alicerces da ponte ameaçam ruir por falta de apoios. Só em 14 de Dezembro de 1996 a erosão do depósito aprofundou mais de $6 \mathrm{~m}$. Neste local, o declive do leito do canal é muito elevado, chegando mesmo a atingir os $15^{\circ}$. A acçãoerosiva desenvolvida pelos processos geomorfológicos que ocorrem nas cheias rápidas é extremamente violenta e promove um grande desgaste destes depósitos.
Fig. 4 - Bacia hidrográfica da Povoação. A. Riba do Purgar (fot. 10 e I1), B. Rib dos Lagos (fot. 12), C. Rib dos Bispos (fot. 13), D. Riba dos Bispos (fot. 14), E. Riba dos Lagos (fot. 15) F. Rib dos Lagos (fot. 16).
Neste caso, parece ter sido determinante a presença da ponte. Esta estrutura exerce dois efeitos importantes: oefeito de estrangulamento sobre ocanal de escoamento e o aumento de declive pela cimentação do fundo do leito no local da ponte. No primeiro efeito, a água adquire velocidade, uma vez que o canal sofreu um estrangulamento que nãoé fácil de alterar por processos naturais. Imediatamente a jusante, aparece o depósito, muito brando, de fácil erosão. Verifica-se, então, um alargamento do vale de tal forma importante que deu origem a um transbordo do canal, deixando um vale abandonado e criando um novo encaixe. No segundo efeito, a acção erosiva sobre o fundo do canal, talhado no depósito, não se exerce no local da ponte uma vez que a camada de cimento funciona como bancada dura, criando o efeito de catarata, aumentando a velocidade de escoamento e, portanto, o poder erosivo do curso de água. A jusante, o aprofundamento do leito é brutal.

$\mathrm{Na}$ Ribeira dos Lagos (fig. 4/B, fot. 12), verificam-se os mesmos efeitos, embora a espessura do depósito seja menor (cerca de $7 \mathrm{~m}$ acima do fundo da ribeira). Neste caso, o alargamento do vale para jusante fez-

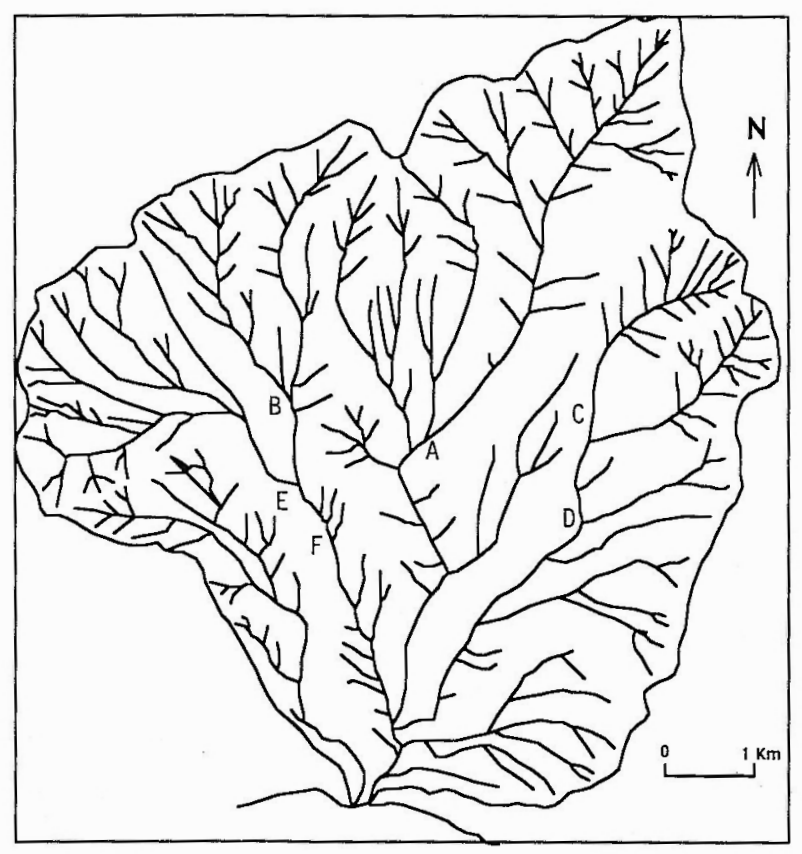

-se por um desmoronamento de terras (à semelhança do que ocorre a montante), resultante do trabalho de sapa imediatamente a seguir aos pilares da ponte, na margem esquerda. Embora não seja tão importante como no caso da Ribeira do Purgar, representa uma dinâmica muito activa, mobilizadora de uma grande carga sedimentar. $\mathrm{O}$ aprofundamento do canal de escoamento, resultante da acção erosiva, resultou num encaixe de cerca de $3 \mathrm{~m}$, só no dia 14 de Dezembro. Também aqui se verifica o efeito de catarata devido à cimentação do leito no local da ponte. Esta é, sem dúvida, uma das acções humanas que mais importância têm sobre a dinâmica fluvial e de consequências determinantes na quantidade de carga fluvial transportada pelas cheias. Alguns quilómetros a jusante, ainda com fortes declives nos perfis longitudinais dos canais de escoamento, é possível verificar efeitos importantes do escoamento sobre os leitos dos canais. A acção mais importante já não é sobre o fundo do canal de escoamento, mas sobre as margens.

$\mathrm{Na}$ Ribeira dos Bispos, o encaixe fez-se num depósito em que a matriz areno-argilosa é extremamente abundante e a presença de calhaus e blocos é muito 
Fot. 12 - Ribeira dos Lagos. Encaixe nos Conglomerados da Povoação e deslizamento na margem direita, a montante da ponte.
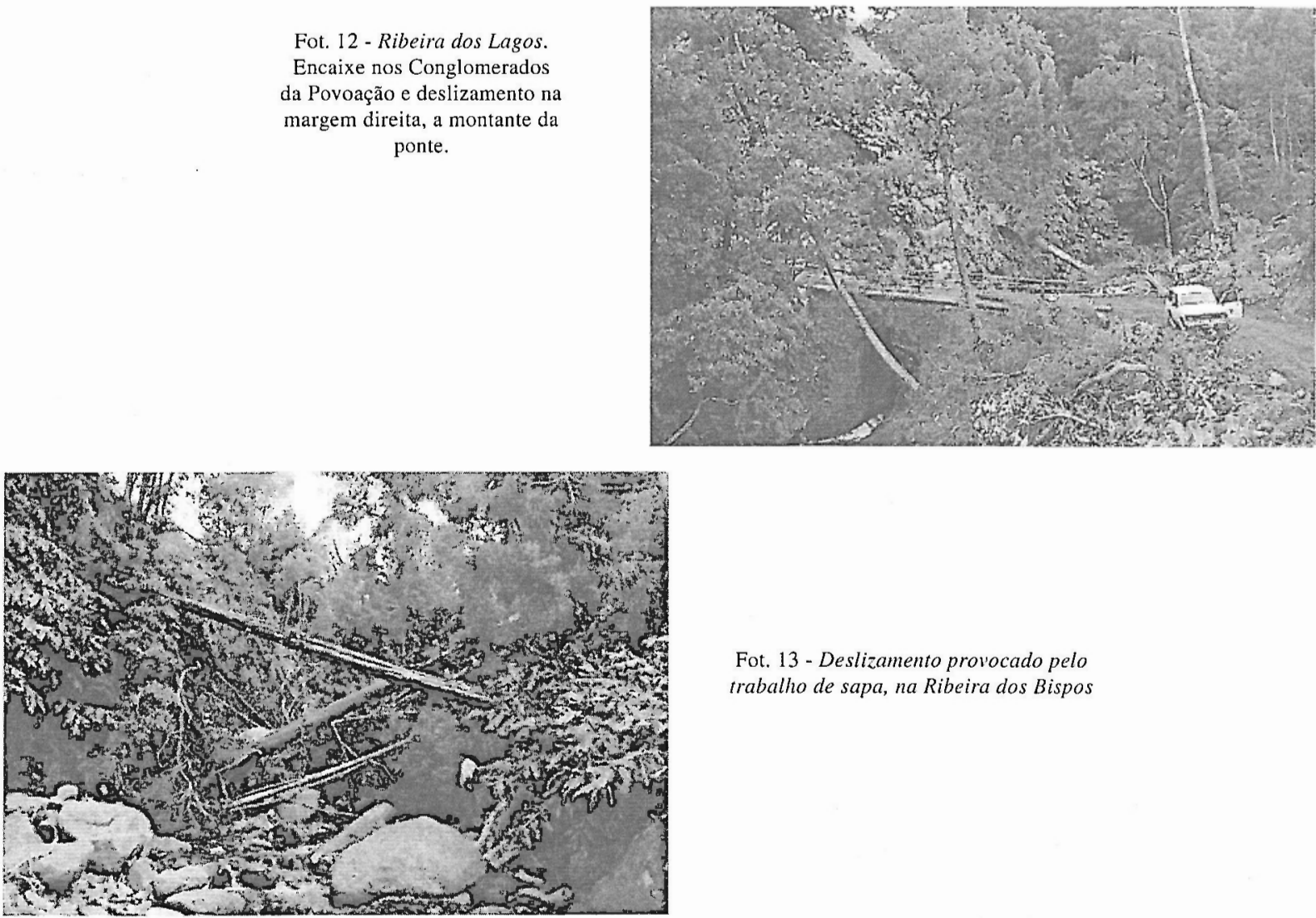

Fot. 13 - Deslizamento provocado pelo trabalho de sapa, na Ribeira dos Bispos
Fot. 14 - Ponte com alicerces afectados pela erosão fluvial. A montante da ponte, em 14 de Dezembro de 1996, processou-se a acumulação de cerca de $2 \mathrm{~m}$ de sedimentos. menor do que nos cortes descritos anteriormente (fig. 4/C, fot.13). Os calhaus e os blocos apresentamse em muito menor quantidade, mas com as características de disposição caótica típicas dos depósitos torrenciais. Apesar de evidenciarem uma dinâmica flúvio-torrencial, a energia gasta para o transporte destes materiais é, sem dúvida, menor do que a necessária para a constituição dos depósitos referidos anteriormente. Com estas características, o trabalho de sapa exercido sobre o depósito provoca o colapso de materiais e árvores que acabam por colmatar o fundo da ribeira, disponibilizando grandes quantidades de material para o transporte torrencial.

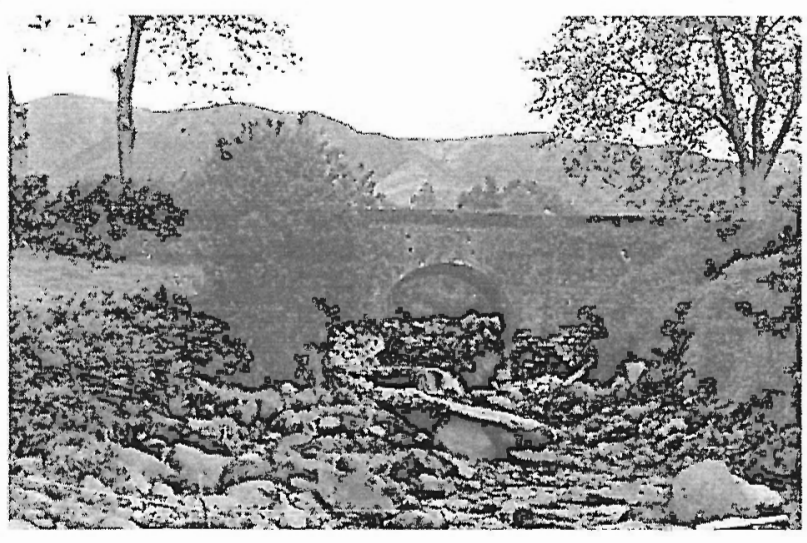

Outro exemplo importante desta poderosa dinâmica fluvial situa-se num meandro abandonado da Ribeira dos Lagos (fig. 4/E, fot. 15). Nesta área, existe uma confluência de um curso de água com a ribeira. Este afluente destruiu uma ponte, escavou o leito em cerca de $2 \mathrm{~m}$ e erodiu parte significativa da margem côncava imediatamente antes da confluência. Uma vez atingida a Ribeira dos Lagos, a onda de cheia retomou o meandro abandonado, destruindo uma quinta aí instalada. Se bem que neste sector o trabalho erosivo seja determinante, a confluência de dois canais com uma grande carga sedimentar criou a necessidade de utilização do meandro abandonado 
para conseguir escoá-la. O alargamento do vale não foi necessário, já que facilmente foi encontrada uma saída para a água e os sedimentos. Uma vez terminada a cheia, o curso de água voltou a ocupar unicamente o leito inicial, situado a uma altitude ligeiramente mais baixa (cerca de dois metros abaixo do fundo do leito abandonado).
Fot. 15 - Meandro abandonado. A cheia de Dezembro de 1996 destruiu a totalidade da quinta, que, entretanto, foi parcialmente reconstruída.

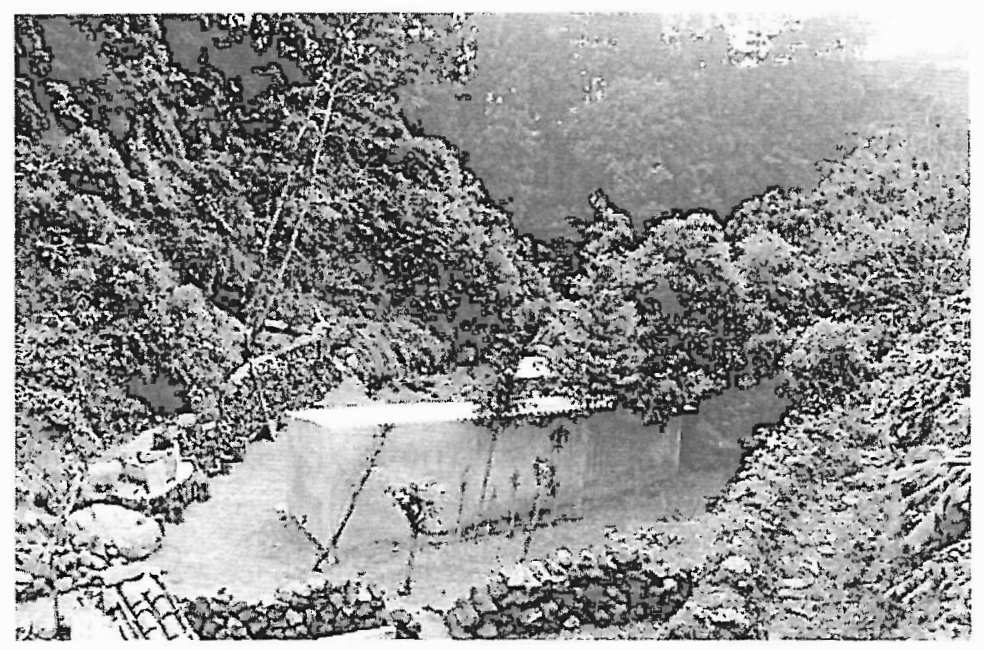

dos canais de escoamento. É frequente verificar-se que a erosão que incide sobre as margens côncavas dos meandros não provoca, de imediato, a queda dos materiais mais grosseiros que, por efeito das raízes, ficam suspensos. Em situação de cheia rápida estes materiais são facilmente mobilizados, uma vez que o pico de cheia acaba por desenraizar as árvores e libertar os blocos, que, deslizando envoltos na lama, percorrem distâncias consideráveis. A mobilização de blocos acaba por se fazer com alguma facilidade, permitindo que a carga sedimentar adquira uma forte acção abrasiva sobre o fundo e paredes dos canais de escoamento. O efeito de escavamento sob os materiais grosseiros é um precioso auxiliar para o início do transporte feito ao longo das cheias. respeito ao efeito de âncora que as raízes das árvores exercem sobre os materiais que constituem as margens

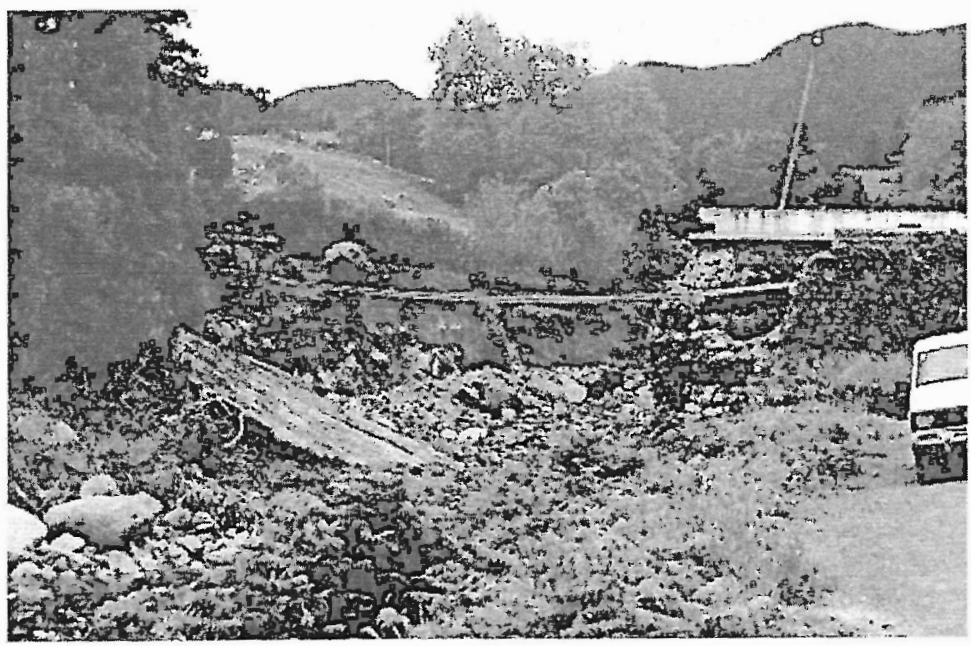

Fot. 16 - Ponte destruída na ribeira dos Lagos. 


\subsection{Perfil longitudinal e processos erosivos}

Operfil longitudinal das ribeiras está directamente ligado à estrutura que constitui a cratera da Povoação. Todas as ribeiras apresentam várias rupturas de declives que coincidem com afloramentos rochosos duros (fig. 5). Ao encaixarem-se, as ribeiras construíram verdadeiros canhões que, em geral, terminam por quedas de água. Imediatamente antes da confluência junto à vila da Povoação, quase todas as ribeiras apresentam um encaixe em canhão que termina por uma dessas rupturas de declive (fot. 17). Nesses sectores, a dinâmica fluvial ganha uma grande energia já que o declive do canal é maior do que a montante. Por outro lado, as paredes e o fundo são constituídos por rocha dura, o que dificulta o alargamento e aprofundamento do vale por processos erosivos naturais. Para caudais muito fortes e grandes cargas sedimentares, o sistema reage aumentando a velocidade de escoamento. Mesmo junto à vila, os sistemas flúvio-torrenciais parecem adquirir uma energia acrescida que advém destas condicionantes morfo-estruturais.
Para além dos canhões situados no sector terminal das ribeiras, é possível verificar que ao longo dos vales das várias ribeiras existem estrangulamentos que correspondem a canhões ou gargantas. Próximo das cabeceiras das linhas de água, os perfis longitudinais têm um declive muito forte aproximando-se do declive das vertentes. À medida que nos aproximamos da superfície das "Lombas", o declive longitudinal diminui bastante (aproximando-se dos $2^{\circ}$ ) e os vales tornam-se abertos ou semi-abertos. As ribeiras perdem o forte poder erosivo resultante do forte declive e depositam parte da carga sedimentar. Passa-se de uma fase de predomínio dos processos erosivos para uma fase em que há alternância do domínio da erosão com o domínio da sedimentação. Com o encaixe na superfície das "Lombas", torna a haver aumento de declives no leito dos canais, sobretudo quando afloram rochas resistentes, criando quedas de água e favorecendo novos encaixes em forma de canhão ou garganta. Na secção média das ribeiras, sobretudo nas Ribeiras do Purgar e dos Lagos, é possível verificar uma sucessão de sectores menos declivosos e sectores onde o perfil das ribeiras tem um forte declive.

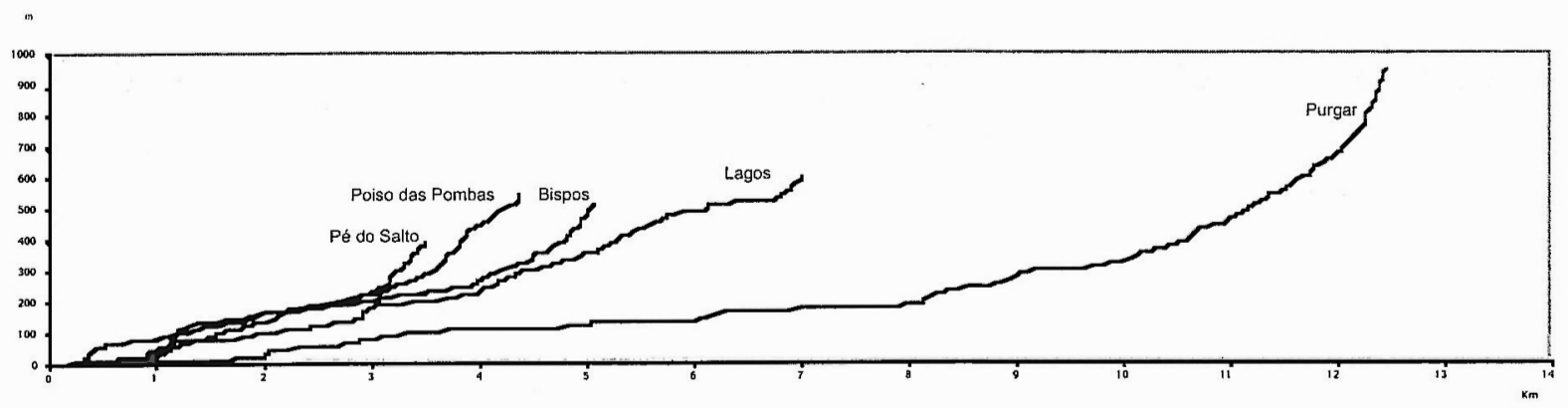

Fig. 5 - Perfis longitudinais das ribeiras da bacia da Povoação.

Fot. 17 - Ribeira de Poiso dos Pombos. O parque zoológico, que foi destruído em 14 de Dezembro de 1996, já se encontra parcialmente reconstruído.

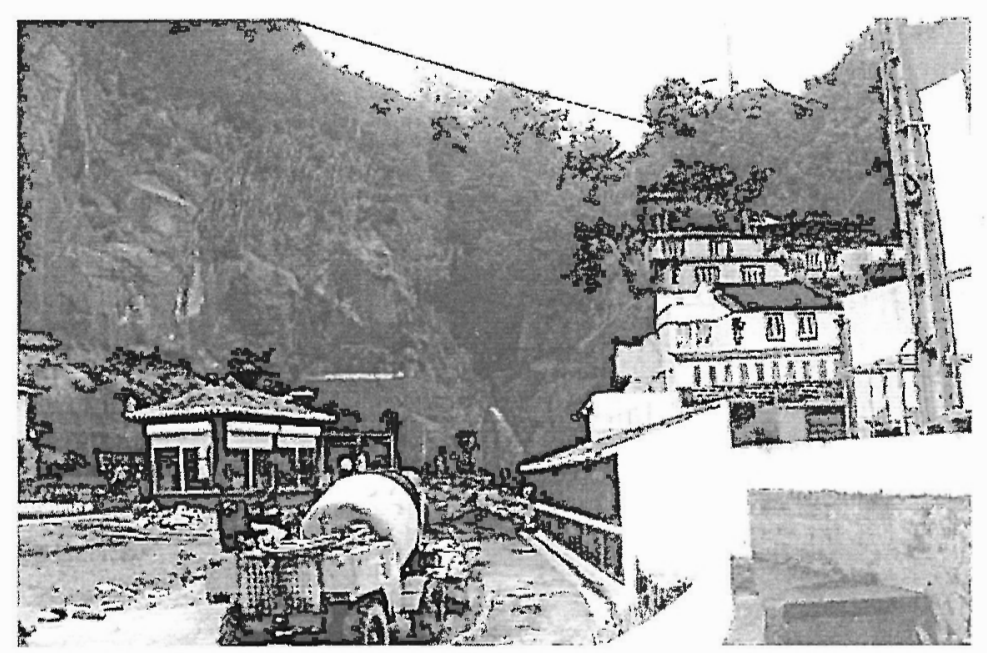




\subsection{Dinâmicatorrencial e unidades geomorfoló- gicas}

A dinâmica torrencial nunca encontra verdadeiras condições para diminuir drasticamente a energia do transporte dos materiais. A morfologia dos canais de escoamento no que se refere, quer ao declive do perfil longitudinal, quer à largura do canal de escoamento, apresenta alternâncias de alargamentos e estrangulamentos que coincidem respectivamente com encaixes em rocha menos dura e em rocha mais dura.

Considerando o sistema flúvio-torrencial das ribeiras que drenam para a vila da Povoação, podemos dividir estes vales em quatro unidades distintas: vertentes de montanha, vales abertos ou semi-abertos, gargantas ou canhões em rocha dura (basaltos), cone de dejecção (figs. 5 e 6 ).

\section{Vertentes de montanha}

As vertentes de montanha apresentam canais de $1^{a}$ ordem. O encaixe das linhas de água é muito fraco, enquanto o declive das vertentes é muito elevado, sendo superior a $30^{\circ}$ na maior parte dos casos. As linhas de água têm praticamente o mesmo declive da vertente e quase sempre estão encaixadas em materiais de fraca dureza. Ao longo destas vertentes ocorrem com frequência movimentos em massa que alimentam o canal de escoamento com grande carga sedimentar. Estes sectores têm escoamento muito rápido, quando das grandes chuvadas, e a sua evolução depende essencialmente da movimentação em massa dos materiais que os constituem. São sectores onde dominam estes processos erosivos.

\section{Vales abertos ou semi-abertos}

Imediatamente a jusante das vertentes de montanha desenvolvem-se vales amplos, com fraco encaixe, de perfil longitudinal que raramente atinge os $5^{\circ}$ de declive. Estes vales apresentam formas suaves e os interflúvios são baixos e largos. Nas linhas de água dominam os processos de deposição sobre os processos de erosão. O escoamento nos canais é permanente e o conjunto de processos geomorfológicos que afectam estes sectores é diverso. Em situação de cheia rápida, quando o transporte sedimentaré dominante, desenvolvem-se grandes deposições no leito do canal que, às vezes, atingem os dois metros. Quando a precipitação é abundante, mas não provoca movimentações em massa nas cabeceiras das linhas de água, os caudais aumentam e o escoamento cria condições para o desenvolvimento de processos erosivos afectando as margens, através do trabalho de sapa. As consequências destes processos erosivos não são muito importantes e, em geral, os materiais transportados são-no em pequenas quantidades e contribuem para o assoreamento parcial de sectores a jusante. Contudo, nestas unidades geomorfológicas, a deposição parece dominar sobre os aspectos erosivos.

\section{Gargantas elou canhões}

Imediatamente a montante da vila da Povoação, os encaixes das linhas de água tornam-se extremamente profundos. De início, apresentam a forma de garganta $\mathrm{e}$, à medida que se avança para jusante, transformam-se em canhões, atingindo frequentemente os $50 \mathrm{~m}$ de encaixe. Os interflúvios são estreitos e alongados e as vertentes têm o topo convexo. É ao longo deles que se foram instalando as populações que os designam por "Lombas". Com encaixes vigorosos, as vertentes tem declives muito acentuados, chegando mesmo a atingir os $50^{\circ}$. Por vezes, os canais de escoamento desenvolvem meandrização encaixada. Nas margens côncavas, o trabalho de sapa é muito intenso, sobretudo em situação de cheia, o que provoca importantes desmoronamentos. Estas áreas, sujeitas a importantes processos erosivos, contribuem com grande quantidade de materiais para a carga sedimentar dos canais de escoamento.

De notar que as unidades geomorfológicas definidas por estes encaixes terminam junto da vila da Povoação e confluem no mesmo cone de dejecção, algumas das quais por queda de água. Nas áreas onde é possível a erosão das margens, a carga sedimentar que o canal de escoamento transporta é acrescida, ao longo das gargantas, pelos desabamentos e deslizamentos. Nos canhões, a erosão dos fundos e margens não é possível, dada a existência de rocha mais dura, e o processo de escoamento e transporte só é possível com o aumento da velocidade de escoamento. Deste modo, a capacidade e competência de transporteé drasticamente aumentada, num sector imediatamente a montante da vila da Povoação.

As gargantas e mesmo os canhões desta unidade geomorfológica estão densamente ocupados por vegetação que, por efeito do trabalho de sapa dos cursos de água, cai e obstrui as linhas de água, criando o efeito de represa que, quando desaparece, contribui para o agravamento dos processos de transporte e deposição na vila da Povoação (F. REBELO, 1997).

\section{Cone de dejecção}

Próximo do mar, o conjunto de ribeiras que constituem a bacia hidrográfica da Povoação convergem num vale encaixado, de vertentes abruptas e de fundo plano. $\mathrm{O}$ aspecto plano do fundo do vale resultou da sedimentação dos materiais que foram sendo transportados ao longo das várias ribeiras. Este sector constitui o ponto de deposição de grande parte da 


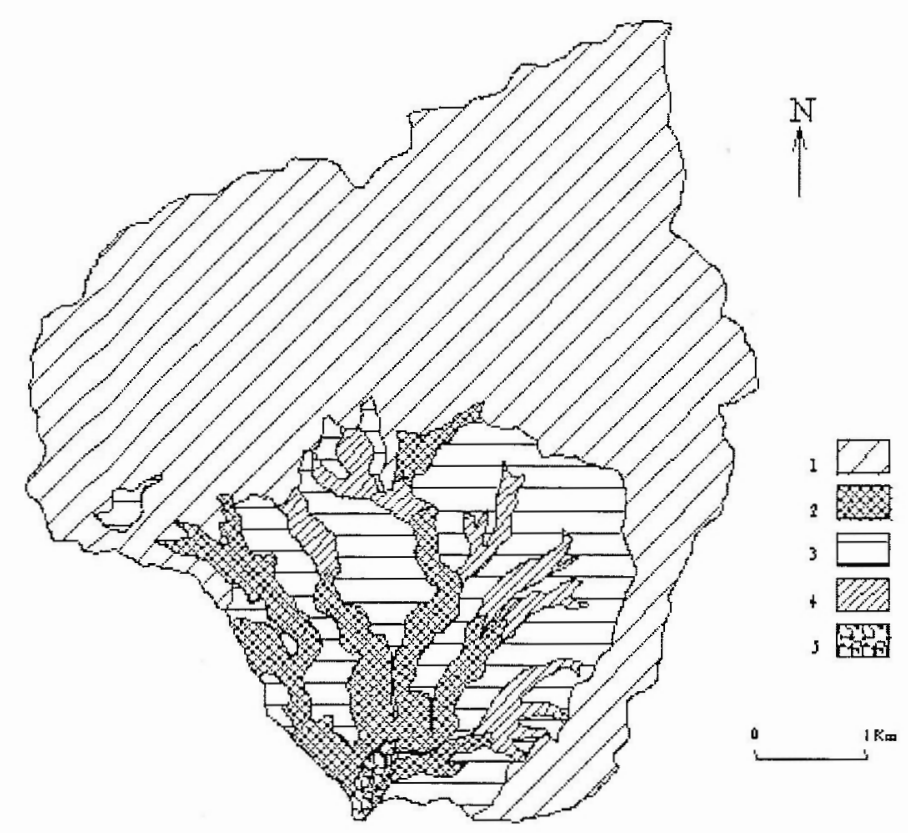

Fig. 6 - Unidades geomorfológicas da bacia da Povoaçäo. 1 - Vertentes de montanha. 2 - Gargantas e canhões. 3 - Superfície das "Lombas". 4 - Vales abertos. 5 - Cone de dejecção. carga sedimentar movimentada ao longo de toda a bacia hidrográfica. Estamos, portanto, perante uma área onde a deposição domina sobre a erosão. É precisamente sobre esta área que se desenvolveu a vila da Povoação. Ocupando o cone de dejecção de todo o sistema flúvio-torrencial, a vila da Povoação está sujeita ao conjunto de processos de erosão, transporte e sedimentação que afectam a dinâmica da bacia hidrográfica.

O desenvolvimento do cone de dejecção parece estar limitado pela acção do mar que promove a erosão da parte terminal, por um lado, e pela acção humana, por outro lado. Assim, a área sujeita a deposição é muito restrita. Entre vertentes abruptas e acção marinha, a área de acumulação é muito estreita e está praticamente ocupada pelas construções. Só um canal ficou livre para o escoamento, embora limitado por margens artificiais. Toda a restante área de acumulação foi ocupada. Sempreque se desenvolvem processos de transporte e deposição que necessitam de ocupar áreas para além desse canal, desenvolvemse os conflitos Homem/Natureza. Neste confronto, em geral, o Homem sofre graves reveses.

Em resumo, cada uma das ribeiras desta bacia hidrográfica é constituída por uma sucessão de várias destas unidades geomorfológicas. Com efeito, a parte superior da bacia hidrográfica da Povoaçãoé constituída por vertentes, a que se seguem os vales abertos ou semi-abertos que progressivamente se vão transformando em gargantas e canhões. Todas acabam por convergir no cone de dejecção da Povoação, algumas das quais por quedas de água. Desta forma, poderemos definir uma cartografia das unidades geomorfológicas onde é possível relacionar os aspectos morfológicos e os processos geomorfológicos numa dinâmica do meio físico com características próprias de cada uma dessas unidades.

\section{Breve análise sobre as hipóteses de intervenção}

\subsection{Os problemas da previsão de cheias rápidas}

Do conjunto de cheias que afectaram a vila da Povoação as que maiores prejuízos causaram foram as cheias rápidas. Conforme já foi referido, um dos aspectos mais importantes diz respeito ao carácter flúvio-torrencial. O processo de escoamento é de tal forma rápido que é praticamente impossível fazer a previsão de cheias a partir da monitorização das precipitações na parte superior da bacia hidrográfica. Aliás, não existe qualquer registador de precipitações na bacia da Povoação, já que os que existiam foram destruídos em 1986 e não foram repostos. Por outro lado, o tempo que medeia entre a ocorrência de precipitação e o desenvolvimento de escoamentos torrenciais é reduzido, o que torna impossível a reacção das autoridades encarregues da protecção civil. Desta forma, os esquemas tradicionais de previsão das cheias, aplicados a bacias hidrográficas de maiores dimensões e com regimes pluviométricos diferentes, não parecem ajustados para a previsão deste tipo de catástrofe natural.

Assim, parece importante antecipar o mais possível o estado de alerta para situações de risco, pelo que o recurso à análise meteorológica regional, utilizando a imagem de satélite, parece ser um instrumento de trabalho essencial. Ao antecipar o estado de alerta, que deverá ter várias fases de desenvolvimento, 
poder-se-ão minimizar as consequências das cheias, especialmente junto das populações mais expostas. Nesse caso, o recurso a metodologias e técnicas alicerçadas na imagem de satélite poderão dar o seu contributo para a antecipação das primeiras fases de alerta. Dessa forma, poderemos ganhar algum tempo que permitirá pôr em marcha a organização básica de protecção civil.

Dadas as dificuldades de previsão das cheias, parece que, no caso da Povoação, o combate aos seus efeitos deverá ser iniciado pelo aspecto da prevenção.

\subsection{Os problemas daprevençãodas cheias rápidas nas áreas mais afectadas}

A prevenção das cheias tem dois objectivos imediatos: minorar as suas consequências e tornar menos frequentese de menor intensidade as mais catastróficas.

\section{Povoação}

As intervenções prioritárias deverão ser feitas junto das áreas em que a probabilidade de ocorrência de cheias é maior. Portanto, em primeiro lugar impõese a definição dos sectores em que a probabilidade de ocorrência de catástrofe é maior. Dentro dessas áreas de maior probabilidade de ocorrência de situações de crise, é necessário proceder a uma hierarquia de prioridades de intervenção. Este trabalho é essencial para uma intervenção eficaz da protecção civil.

Mas torna-se igualmente urgente a elaboração da cartografia de riscos naturais que ajude a promover as medidas necessárias à prevenção da perda de vidas e das destruições de equipamentos dispendiosos.

A solução mais eficaz para a resolução definitiva do problema das cheias na Povoação consistiria na transferência de toda a vila para fora do cone de dejecção. Nas áreas mais elevadas é possível encontrar locais onde o risco de movimentações em massa seja mínimo e colocar as populações ao abrigo das cheias. Nesse sentido surge, novamente, como muito importante a elaboração da cartografia de riscos naturais.

\section{Sectores a montante da vila da Povoação}

Os trabalhos de limpeza e desassoreamento das ribeiras constitui um dos esforços essenciais para que se evite o efeito de represa e não se agravem as condições de escoamento nos canais que atingem a vila da Povoação. Embora estas sejam as medidas elementares que necessitam de trabalho e assistência permanente, há um conjunto de medidas que poderão ser implementadas e que urge debater. A construção de barragens que funcionem como amortecedores de impacto de cheia constitui uma solução, cujo funcionamento técnico deverá ser analisado cuidadosamente. Cada barragem deverá ter uma dimensão estudada de forma a ser capaz de suster grandes quantidades de água e materiais grosseiros. A estrutura deverá ser bastante resistente já que, caso haja ruptura, a catástrofe atingirá níveis superiores aos que se verificariam sem barragem.

Por outro lado, estas estruturas deverão estar livres de qualquer outra utilização (produção hidroeléctrica, turismo) já que não há qualquer hipótese de reacção em tempo útil que permita o esvaziamento da barragem e, com isso, disponibilizá-la para o efeito de amortecedor de cheia. Supondo que existe uma barragem repleta de água, em situação de crise o transbordo não pode ser evitado, e a erosão provocada pela queda de água, a jusante da barragem, será importante. Grandes quantidades de água carrearão sedimentos com forte poder erosivo e um grande potencial destruidor. Tais processos erosivos poderiam ainda pôr em risco os alicerces da barragem o que levantaria graves problemas de manutenção de toda a estrutura.

Estes sistemas nunca poderão ser analisados isoladamente. Não nos parece suficiente a construção de uma única barragem, mas sim de um sistema de açudes e barragens abertas, com estruturas capazes de suster e reter a grande carga sedimentar (sobretudo os blocos de maiores dimensões e as árvores). $\mathrm{Na}$ tentativade evitar a acumulação de carga sedimentar e diminuir o poder destrutivo da onda de cheia, poderiam ser construídas algumas estruturas nas unidades geomorfológicas de "vales abertos ou semi-abertos", cuja função consistiria na retenção de toda a carga sedimentar mobilizada pelos movimentos em massa que ocorrem na unidade geomorfológica "vertentes de montanha".

Posteriormente, deveriam ser criadas estruturas que retivessem toda a carga sedimentar mobilizada nas unidades geomorfológicas "gargantas e canhões". Estas seriam as de mais difícil construçãoe constituiriam um último resguardo da vila da Povoação em relação ao transporte de sedimentos ao longo da bacia hidrográfica.

Para além do efeito de retenção da carga sedimentar, as estruturas a construir deveriam retardaro escoamento, diferindo, no tempo, a acção e amplitude da onda de cheia que atinge a vila da Povoação. E como o normal funcionamento das torrentes iria entulhando essas estruturas, seria necessário implementar um esquema de manutençãoperiódica que as mantivesse operacionais. 


\section{Bibliografia:}

AMARAL, I. (1968) - "As inundações de 25/26 de Novembro de 1967 na região de Lisboa". Finisterra, Lisboa, 3 (5), 79-84.

BRITO, R. S. (1955) - A ilha de S. Miguel. Centro de Estudos Geográficos, Lisboa, 214 p.

FERREIRA, D. B. (1980) - Contribution à l'étude des vents et de l'humidité danslesîles del'archipel des Açores. CEG, Lisboa.

FERREIRA, D. B. (1985) - "Les depressions convectives du bassin atlantique nord subtropical oriental". Finisterra, Lisboa, 20, (39), p.25-45.

GODINHO, S. F. (1984) - Aspectos meteorológicos das inundações de Novembro de 1983. I.N.M.G., Lisboa, 57 p.

GOUDIE, Andrew (1986) - The human impact on the natural environment. Basil Blackwell, Oxford, $338 \mathrm{p}$.

GREGORY, K.J.e WALLING, D.E. (1973)- Drainage basin: form and processes. A geomorphological approach. Edward Amold, London, $458 \mathrm{p}$.
PETTS, Geoffrey E. (1983) - Rivers. Col. Sources and Methods in Geography, ed. M. A. Morgan e D. J. Briggs. Butterworths. London. $228 \mathrm{p}$.

REBELO, F. (1985) - "Identificação de processos geomorfológicos actuais na parte ocidental da ilha de S. Miguel (Açores)", Cadernos de Geografia, Coimbra, 4, p.121-139.

REBELO, F. (1997) - "Risco e crise nas inundações rápidas em espaço urbano. Alguns exemplos portugueses analisados a diferentes escalas". Territorium, Coimbra, 4, p.29-47.

REBELO, F e RAPOSO, A. G. (1988) - "As inundações de 2 de Setembro de 1986 na Povoação e no Faial da Terra (S. MiguelAçores)", Cadernos de Geografia, Coimbra, 7, p.169-179.

SANTOS, J. Marinho dos (1987) - Os Açores nos séculos XV e XVI. Coimbra.

SILVA, J. M. A e (1995), A Madeira e a construção do mundo atlântico (séc. XV-XVII). Funchal, CEHA. 